\title{
Specialization and the firm in Renaissance Italian art
}

\author{
Ennio E. Piano*
}

\begin{abstract}
Renaissance Italian painters are among the most innovative and consequential artists in human history. They were also successful managers and business owners, always in search of commissions for their workshops. Indeed, their ability as managers and entrepreneurs was just as important as their talent for painting. This paper develops a framework to understand the organization of the production of paintings - frescoes and altarpieces - during the Italian Renaissance. We argue that Renaissance artists faced a trade-off between costly delegation and the sacrifice of gains from specialization in the performance of those tasks necessary for executing a painting. Applied to the historical record, our framework accounts for several features of the organization of this industry: why Renaissance artists dabbled as entrepreneurs; why they performed several duties that did not require any artistic talent; and why they set up firms to aid them in the execution of some tasks while delegating other tasks to independent contractors.
\end{abstract}

Keywords: Firm boundaries; Renaissance art; Specialization

JEL Codes: D23; N64; Z11

\footnotetext{
*Jones College of Business, Middle Tennessee State University. Email: Ennio.Piano@mtsu.edu. This manuscript is a much-revised version of a paper circulated under the title Organizing artistic production. Many thanks to Clara Jace, Caleb Fuller, Bryan Cutsinger, and Mario Ferrero for providing helpful comments on previous drafts. I am especially thankful to Edtior Federico Etro, one anonymous referee, Brian Albrecht, Doug Allen, Darlene Chisholm, Sheri Shaneyfelt, and Paola Suarez.
} 


\section{Introduction}

The Renaissance - a period of European history going from roughly 1300 to roughly 1520 — marked the beginning of a new stage in art history. Much of what we associate with the idea of art in the West today had its origins in this period. For instance, it's during the Renaissance that painting assumed its place as the queen art form, overtaking the previously more popular mosaics and tapestries. It was also a period of rapid artistic innovation, as painters developed several new techniques and styles within just a few generations. For example, it was during this period that masters introduced one- and two-point perspective techniques by applying principles from the study of optics and geometry, enabling them to reproduce a three-dimensional world on a twodimensional medium (Nethersole, 2019, 121-3, 130-1). Renaissance painters pioneered the study of human anatomy, as this knowledge was necessary to give the figures in their paintings and their movement a life-like appearance (Nethersole, 2019, 153-4). They also developed new methods for the production and use of pigments - first with the invention of the egg-based tempera and later with that of oil paint ${ }^{1}$ - as well as for the preparation of surfaces for the painting on walls and wooden tables (Vasari, 1998).

The very notion of an artist emerged during this period. It is only then, for instance, that painters started signing their work (Welch, 2000, 124). There began to be a sense that the visual artist was more than just a craftsman, an artisan who had mastered a certain set of skills and techniques. The painter was now seen as having the unique ability of picturing in his imagination a complete art work that could produce expected emotional reactions - wonder, sorrow, joy - on the part of the viewers (Vasari, 1998). The painter achieved this effect through his choice of subject, composition of figures, their facial expressions, the movement of their bodies, and through the use of color (O'Malley, 2013, 64-5). Renaissance art theorists, many of whom were themselves successful painters in their time, referred to this ability as ingenio, which they distinguished from the concept of arte, or the technical ability to execute the artist's vision. In this view, someone with arte may be able to replicate Botticelli's Birth of Venus, but only Botticelli's ingenio could bring the original into existence.

Renaissance art theorists thought that ingenio, or artistic talent, was fundamentally innate. No amount of effort, no length of apprenticeship at the side of an established painter could compensate for it: "[A]ny artist who is not fit for a task will never, strive though he may, reach the level to which another artist may easily progress with the help of Nature" (Vasari, 1998, 335). However, they recognize that to reach the highest ranks of artistic achievement, this innate talent had to be cultivated:

\footnotetext{
${ }^{1}$ Oil paint was first first developed by a Flemish artist, Jan van Eyck, but rapidly adopted by Italian ones over the fifteenth century (Vasari, 1998, 186-7).
} 
Study and natural talent need to be joined to reach the height of perfection in painting $[\ldots]$ and whenever one of the two qualities is missing, the artist rarely reaches the summit, although study may well carry him most of the way. ${ }^{2}$

Even still, ultimately, "no amount of such training and education can automatically produce a masterpiece" (Bondanella and Bondanella, 1998, xii).

On the other hand, while necessary, no amount of ingenio was sufficient to produce a masterpiece, either. Renaissance paintings were complex artistic products. The exercise of arte in their execution was also necessary. This required the performance of a wide array of tasks of varying artistic content, from the design of the painting to the drawing of figures, from the grinding of pigments to the laying of gesso on wood panels or walls. Poor execution could compromise the artistic vision of painters with the most ingenio (Vasari, 1998, 202-3). Even the the latter did not focus all their time and effort on the exploitation of their natural talent as may be demanded by the principle of comparative advantage. In fact, Renaissance painters did much more than that. They contributed to virtually every phase of the production process, whether directly or indirectly, including making preparatory drawings, applying pigments on the medium's surface, and even performed tasks, like the transportation and assemblage of the final work, that did not require any particular artistic talent at all. However, if they had executed all these tasks alone, their output would have been greatly diminished. Instead, they worked in tandem with others. Renaissance art was ultimately the result of team effort and the notion of autograph work - i.e., the idea that a painting had been made entirely by one artist - did not exist. Most renowned Renaissance painters were essentially entrepreneurs who started their own firms, known as botteghe or workshops, and employed skilled and unskilled workers to assist them in the fulfilment of commissions. For some of these tasks, they also relied on specialized workers, independent contractors - like gilders and carpenters - who operated their own workshops.

A painter's ability to manage his bottega and deal with patrons and independent contractors were essential to his success: "Only with good supervision and the intelligent direction of numerous skills could master painters bring about a large quantity of work and create the works of excellence that satisfied their clients and upheld their reputations" (O'Malley, 2013, 173-4). In this and other regards, Renaissance painters differ substantially from present-day visual artists (Caves, 2000). The latter seldom work on commission or interact directly with potential buyers. They also tend to perform but a small subset of the tasks their Renaissance predecessors did. Today

the whole apparatus for the preparation of pigments, media, and varnishes has disappeared. It would be difficult to find today a painter who owned, much less used, the

${ }^{2}$ Vasari $(1998,232)$. 
stone slab and muller ... which was used to grind pigments to powder and incorporate them into the medium with which they were mixed. ${ }^{3}$

Only rarely are contemporary visual artists even able to "fasten a piece of canvas to its stretcher, and prepare [their] own grounds on panels and canvas" and most materials they purchase ready for use (Constable, 1954, 23). Finally, contemporary visual artists do not generally run a business like the Renaissance bottega, supervising skilled and unskilled workers' contribution to all stages of production, and buyers expect an autograph painting to have been produced entirely by the artist who signed it, not by some nameless assistant.

The purpose of this paper is to explain some key features of the organization of the supply side of paintings in the Italian Renaissance. To this end, we develop a simple model of the production of a Renaissance painting to motivate our analysis. ${ }^{4}$ A painter and an artisan may come together to exploit their comparative advantage in the performance of creative and mundane tasks respectively. However, the presence of hidden effort requires that one of them assume ownership of the bottega and monitor the other's performance. According to our argument, the optimal ownership allocation depends on the relative cost of monitoring the performance of creative and mundane tasks. From this we can derive the first empirical proposition of our paper: Since the cost of the former generally exceeded that of the latter, painters would have tended to own the firm and direct and monitor the artisans' work and not vice versa. Once they have assumed ownership of the bottega, painters face the choice of whom to allocate the performance of the mundane task. The alternatives available to them are a) delegation to an employee of the firm, b) delegation to the market (i.e., to an independent contractor), or c) to perform the mundane task themselves, what Barzel (1987) refers to as "self-policing." Delegation has the advantage of exploiting the benefits from specialization, but comes at the cost of monitoring performance or measuring its outcome. Self-policing, on the other hand, economizes on the costs of delegation but sacrifices any gains from specialization. Thus, the optimal allocation of tasks by an artist-owner will depend on the relative magnitude of delegation costs (within the firm and on the market) and gains from specialization. Two further empirical propositions follow from this discussion. First, masters will keep in the bottega those mundane tasks with relatively low costs of direction and supervision and delegate to the market those tasks for which appraisal of performance can be easily done upon purchase. Second, painter-owners will forego the benefits of specialization and "self-police" the performance of which can only be delegated at a significant cost.

We test our framework against the historical evidence on the organization of the production of paintings in Renaissance Italy from a variety of primary sources, contemporaneous secondary

${ }^{3}$ Constable $(1954,22)$.

${ }^{4}$ Our model is meant simply to frame our argument and identify the key variables of interest for our discussion of the historical evidence. 
sources, and modern secondary sources. Unfortunately, evidence of the inner workings of painting botteghe in the Italian Renaissance is scant. Since much of the economy still operated in a rather informal fashion, documentation for labor and other types of contracts was not as common as it is today. And of those documents that were produced, only a small fraction has survived since. Moreover, very few masters from this period wrote direct accounts of their business operations.

Our primary sources consist of seventy-six individual commission contracts (or allogazioni) for paintings from Italian masters between 1285 and 1524. Some of these commissions were signed by the Renaissance's most esteemed painters - like Piero della Francesca, Sandro Botticelli, and Raphael - and related to the production of some of the most famous pieces of art ever produced, like Duccio's Maestà and sections of the Sistine Chapel. ${ }^{5}$

For our contemporaneous secondary sources, we rely mostly on two documents that have greatly influenced art historians' understanding of the practice of painting during this period. The first is Cennino Cennini's Libro dell'Arte, often translated as The Craftsman's Handbook. Cennini was a painter in the tradition of Giotto who worked in Florence in the first half of the fifteenth century. He wrote his Handbook during this period as a manual for aspiring painters. This document provides a detailed contemporaneous account of the techniques any competent painter from this period was expected to know and master.

The second contemporaneous work on Italian Renaissance painting is Giorgio Vasari's Vite dei Più Eccellenti Pittori, Scultori e Architetti, often translated simply as Lives of the Artists. Vasari was also a Florentine painter, and a highly respected one at that. His Vite contain accounts of the lives and works of over two hundred Italian artists, most of them painters, from the Thirteenth to the Sixteenth centuries. While his approach is largely that of biography and art criticism, his accounts provide several insights on the business aspect of painting, including the commissioning process and the inner workings of the bottega.

Finally, we rely on several modern contributions at the intersection of business and art history. Among these, the most relevant to our subject are O'Malley's work on the process of commissioning paintings in Renaissance Italy (O'Malley, 2005) and on the role of artists' reputation in the same market (O'Malley, 2013), as well as Thomas' study of that day to day operation of Renaissance painters' workshops (Thomas, 1995).

The historical record is consistent with the implications of our model. It shows that the Renaissance art market in Italy was characterized by the following patterns. First, patrons commissioned their art work to artists who had proven their ingenio in previous work. By accepting a commission, artists assumed all liability over the complete product. Second, artists kept exclusively for themselves the most conceptual phases of the production process. Third, they performed

\footnotetext{
${ }^{5}$ Translations of passages from these contracts are the author's unless otherwise noted.
} 
other tasks, especially ones that most closely embodied their vision of the final painting - such as its design, preparatory drawings, and the painting of all major figures, especially their faces. They also performed tasks that, while requiring no arte, they could not evaluate easily and may cause severe damage to the painting if executed without care. Fourth, if artists could evaluate a task's execution by monitoring and supervising it directly, they assigned that task to members of their firms. If they could do so by observing the task's outcome upon purchase, they left it to independent contractors.

Our argument sheds light on key aspects of the organization of business activity in what was a sizable sector of the urban economy in Renaissance Italy. ${ }^{6}$ While data limitations prevent us from establishing the share of the domestic product of major Italian art centers attributable to this industry, anecdotal evidence indicates that it was significant. For instance, there were in Florence, in the first half of the fifteenth century, forty-one master painters (Wackernagel, 1981, 299-301). Since many painters did not officially register as such with any of the city's guilds, this is likely an underestimate of the number of workshops one would have found there at the time. The number is particularly impressive when compared to the same figures for silk-weavers (eighty-three), wood-carvers (eighty-four), and goldsmiths (forty-two). Dozens of other notable painters operated botteghe out of Venice, Rome, Siena, Bologna, and Perugia, resulting in highly competitive national and regional art-markets (Nethersole, 2019; Etro and Pagani, 2012; Etro, 2018). Under such strong competitive pressure, organizational choice is key to business survival (Fama and Jensen, 1983). Poorly aligned incentives due to the misallocation of residual claimancy or tasks within and outside of the bottega would have compromised the masters' ability to break even. Ultimately, it may also have prevented the production of many of the masterpieces for which the Italian Renaissance is celebrated to this day.

\section{Literature review}

This article contributes to the literature studying the effects of transaction costs on the organization of economic activities and the degree of division of labor in society. Like Stigler (1951), Barzel (1987), Becker and Murphy (1992), and Allen and Lueck (1998), we treat the extent of specialization in the performance of productive tasks as endogenous. Unlike Barzel's, our framework encompasses the choice to govern tasks within one firm or across firms. Unlike Becker and Murphy's and Allen and Lueck's, our framework does not see the integration of tasks in the firm as necessarily reducing the degree of specialization, but rather as an alternative way of allowing

${ }^{6}$ The focus on Italy is justified by the disproportionate role that the region plaid in the overall art scene of the Renaissance. According to one calculation, Italian artists "dominated totally" the European market throughout the period (Kelly and O'Hagan, 2007). 
for specialization to take place. Within our framework, only the direct performance of a task by the entrepreneur, which Barzel dubs "self-policing," actually reduces the degree of division of labor in the economy.

The article also contributes to the analysis of art markets from the perspective of organizational economics. Caves (2000) and Caves (2006) apply tools from contract theory and information economics to study the institutions of contemporary creative industries, including the visual arts, the music industry, the movie industry, musical theater, and the publishing industry. In a similar vein, Chisholm (1993) and Chisholm (1997) investigate contract choice in the motion picture industry during the twentieth century. She finds that studios were more likely to compensate actors with a share of box-office revenues the lengthier their contract, the more experienced they were, and the higher their expected effect on the box-office numbers. She also finds that the lower degree of asset specificity of the studios' investment in their actors following the "Age of the Studio" was responsible for the decline of fixed salaries to compensate actors. More recently, Etro and Pagani (2012) and Etro (2018) find empirical support for the hypothesis that contracts between Renaissance painters and their patrons are consistent with the "informativeness principle" introduced by Hölmstrom (1979): The price of a Renaissance painting increased in the value of measurable characteristics - like size and number of figures - correlated with the painter's effort.

Our article contributes more generally to the cultural economics literature, especially as it relates to the market for paintings. Owen (1977) made an early contribution to this field by developing an explanation of the emergence of strikingly different pictorial styles between the Florentine and the Sienese schools during the early Renaissance. Owen attributes this development to the fact that, in both cities, patrons enjoyed significant monopsony power and employed such power to force their thematic and stylistic preferences on local painters. Since the sensibilities of the Florentine and Sienese elites were rather dissimilar - rationalistic and naturalistic those of the former, religious and traditional those of the latter - so was the look of the paintings produced by local artists. Our contribution follows Owen's by explicitly applying economic models to the study of Renaissance art markets. Particularly relevant to our contribution is Etro (2018), who provides an empirical analysis of the primary market for paintings in Renaissance Italy. Relying on information from over three hundred commissions from the period, Etro finds that the prices of paintings varied systematically with such variables as their size, number of figures, and the reputation of the commissioned painter. He also finds that this market experienced a significant degree of competition: Painters moved from one town to another and ventured into different genres of paintings to take advantage of any profit opportunity, leading prices to equalize across local markets and genres. This result puts further emphasis on the importance of Renaissance master's managerial ability. In order to survive such competitive pressures, painters needed to structure incentives as effectively as possible within their bottega and in their interactions with independent 
contractors. Etro and co-authors (Etro and Pagani, 2013; Etro et al., 2015) find similar results when investigating the art markets of early modern Venice and Rome.

In the same vein, De Marchi and Van Miegroet (2006) provide an analytical treatment of the history of the market for paintings in Western Europe from the fourteenth to the eighteenth century. For instance, they argue that the Flemish market for paintings during the 1400s was "larger [and] more vibrant" than that of Tuscany (De Marchi and Van Miegroet, 2006, 109). This allowed for more competition, stylistic experimentation, and emulation between artists, which they identify as the key factor behind the higher degree of innovation one finds in fifteenth century Bruges than in Florence. Closer to our emphasis on organizational issues, they discuss the effect of the rise of art dealers after the sixteenth century. They note that the vertical integration between painters and art dealers affected the former's incentives for invention. Unlike under the commission model that dominated Renaissance Florence, the dealer-artist joint venture presumed that any original painting would be copied and marketed by the dealer to a wider audience. Thus, the more popular the invention as expressed in the original, the more copies will be sold, the higher the return to the artist's invention.

The work of Montias $(1987,1990)$ takes a more socio-economic approach to the study of historical art markets. For instance, Montias (1987) argues that the rise of anonymous markets for paintings, which would eventually displace the patronage model, was due to a confluence of social and economic forces. On the demand side, he claims that the protestant reformation in the Flanders had the unintended effect of increasing the demand for religiously themed paintings from Catholic households who had been forced to have religious services in the privacy of their homes. This process was part of a broader realignment of the demand for paintings from religious institutions to private individuals, which in turn resulted in the abandonment of the previously popular history paintings for "portraits, landscapes, and still-lifes" (Montias, 1987, 459). On the demand side, the introduction in the seventeenth century of new production methods and technologies "lowered the costs of producing paintings and enabled artists to penetrate new markets" and thus facilitated the movement to a broader market for paintings (Montias, 1987, 459).

More recently, cultural economics scholars have been extending econometric techniques to the study of the market for paintings. Galenson and Weinberg (2000) and Galenson (2011) have provided strong evidence supporting the thesis that there has been a structural shift in the practices, emphases, and age-cycle of American visual artists during the twentieth century. For instance, they find that artists born after 1920 "peaked" in their late twenties, which is much earlier-indeed, almost two decades earlier - than it had been for the previous cohort. They attribute this change to the sudden shift in the sensibilities of art critics and collectors during the 1950s, which now emphasized change and innovation over technique as summarized by the motto "the greater the changes, the greatest the artist" (Galenson, 2009, 4). This development, they 
argue, favored younger artists who could more readily come up with "conceptual innovations" at the expenses of more experience ones, whose contributions tend to take the form of experimental adjustments over several decades (Galenson, 2009). Etro (2018) find some evidence of conceptual and experimental life-cycles among Renaissance painters. For instance, he argues that conceptual innovators like Raphael produced their most popular work at a young age, while more experimental innovators like Leonardo da Vinci achieved greater success in their late thirties and forties. These contributions focus mainly on the interaction of the forces of demand and supply to determine the variation in the price of paintings in the primary and, in the case of Galenson and Weinberg (2000), secondary art markets. Our paper complements these works by providing an analysis of the forces that shaped the internal organization of the firms that operated on the supply side of the market for paintings in Renaissance Italy.

Greenwald (2021) mixes qualitative and quantitative methods to the study of art history. For example, the book investigates the economic roots of female painters' representation in nineteenth century American art. Using data on expositions from the National Academy of Design and data on contemporary collections from the Metropolitan Museum of Art, she provides empirical support for the hypotheses that female painters' underrepresentation was likely due to the fact that the most prestigious genres during this period-like landscapes, history paintings, and portraits - were highly time intensive. Nineteenth century female painters were much more likely to focus on genres, like still-lifes, that were less time sensitive but also held in lower regard by critics.

Finally, our argument relates to the cultural economic literature on geographic clustering and artistic productivity. Kelly and O'Hagan (2007) find that Renaissance Italian painters clustered in a handful of cities, with Florence dominating the market for most of the period. They argue that such clustering was likely due to a combination of factors. First, wealth concentrated in larger cities, offering more opportunities for painters than smaller centers. Also, cities may have provided artists with significant artistic freedom due to the large number of independent and competing patrons on the demand side. Finally, the proximity of painters' workshops in cities allowed for knowledge spillovers between masters, making easier the adoption of innovative styles and techniques and thus increasing artistic productivity overall. The role of knowledge spillovers and clustering in the arts is supported by a growing body of knowledge. For instance, Hellmanzik (2010) finds that modern visual artists enjoyed a significant productivity increase when moving from a minor center to Paris, the art-world's capital through the second half of the twentieth century. These results are further confirmed by Borowiecki (2013) who finds that increased artistic productivity is due to the clustering premium and not to self-selection of more productive artists into major cities. During the nineteenth century, moving to a major artistic cluster could increase a classical music composer's productivity by between twenty-five and fifty percent, or one extra 
major composition every two to three years. There is also evidence that spillover effects affect the content, as well as the number, of artworks. Greenwald (2019) argues that the growing popularity of rural imagery as the subject of paintings at the prestigious Paris Salon in the nineteenth century was due to the rise of artists colonies in the country-side, non-urban clusters made possible by the drastic reductions in transportation costs due to the modernization of the French economy.

While knowledge spillovers-generated clustering can have profound effects on the nature and evolution of art markets, it cannot account for the specific organization of the Italian Renaissance painter's workshop. The presence of spillover effects between master painters cannot explain why, of all the specialized workers involved in the production of paintings, the artist was the one who assumed residual claimancy and liability over the final painting. Nor does it explain why artistowners would choose to retain for themselves certain tasks while entrusting the rest to either workshop laborers or independent contractors. Knowledge spillovers can explain why the presence of renowned painters in cities like Florence and Venice attracted others to the same centers, not the way they choose to organize their business. However, knowledge spillovers may be said to be responsible for the organizational form of the Renaissance bottega if the latter existed to facilitate the transmission of knowledge and techniques between artists. To the contrary, the historical evidence shows that the workshop brought together individuals with largely complementary skills. Many members of a bottega were employed in artisanal tasks, not artistic ones. To the extent that artistic knowledge was transmitted between members of the same bottega, it was between a master and his apprentice. But this relationship differed from the standard spillover argument in important ways. First, it was unidirectional. It was the apprentice who learned from the master, not vice-versa. Second, the transfer of knowledge was voluntary. Apprentices compensated their masters in the form of cheap or zero-priced labor and, sometimes, in the form of direct payments (from the apprentices' families). Thus, knowledge spillovers were effectively internalized. ${ }^{7}$ Finally, the apprenticeship was at most a secondary feature of the Renaissance workshop. The presence of apprentices in a workshop was neither necessary nor sufficient to the production of a painting. Indeed, even as major art centers like Florence, Rome, and Venice instituted professional schools dedicated to the training of young artists during the late Renaissance and Baroque period, this did not lead to the disappearance of the painter's workshop. ${ }^{8}$

\section{The Renaissance market for frescoes and altarpieces}

The development of Renaissance art was propelled by the rapid economic growth and urbanization of the Late Middle Ages. Up to that point, visual artists had worked mostly in the countryside,

\footnotetext{
${ }^{7}$ Note that in this way the institution of the bottega reduces the magnitude of spillover effects properly understood. ${ }^{8}$ On the rise of these Accademie delle Arti see Spear and Sohm (2010).
} 
employed at the court some noble family or at a monastery (Nees, 2002; Sekules, 2001). With the Italian urban centers growing in wealth and population, there was a new source of demand for the artists' services: their many newly-built churches, chapels, and public palaces needed to be decorated (Goldthwaite, 1993). Nowhere was this development so pronounced as an in the Italian center-north. Cities like Bologna, Florence, Perugia, Siena, and Venice became hubs for artistic excellence, developed their own "schools" of painting, and began exporting their products to the rest of the Italian peninsula (Berenson, 1980).

The demand for Renaissance art was largely a demand for paintings, which had surpassed mosaics and tapestries as the most popular art form by the late thirteenth century (Etro, 2018). Due to the nature of this demand, most paintings had religious subjects and themes, such as scenes from the Old Testament, the Gospels, or the lives of Saints (Sekules, 2001; Welch, 2000). ${ }^{9}$ There was also some demand from the governments of the Italian cities for representations of patriotic episodes - real or imagined - from their history, aimed at reinforcing local pride and support for the ruling regimes (Berenson, 1980). Only later in the Renaissance, there emerged a demand for other subjects, such as portraits and scenes inspired by classical mythology (Nethersole, 2019).

The two most popular kinds of paintings during this period were frescoes and altarpieces. A fresco is a painting decorating the surfaces of walls and ceilings, generally those of a church or a palace. Frescoes had become popular in the Late Middle Ages as they offered "a faster, cheaper, and more durable alternative to cloth or tapestry, whose design it often imitated" (Welch, 2000, 66). The fresco technique was quite innovative. After a full-scale drawing of the final painting on a large sheet of paper had been completed, the painter would apply a mixture of lime water and ashes onto the wall and immediately began transferring the image from the cartoon onto the wall using a pointed stick. Once the drawing had been transferred, he would rapidly apply the paint - usually watercolors - onto the still-wet surface.

The frescoing process was time-sensitive and required great precision as the painting could only take place before the surface had dried. Hence, on any one day, the painter could work only on a small section of the painting. However, this technique had significant advantages. The final painting required no protective coating and naturally maintained its qualities and brightness for hundreds of years since, by painting while the wall was still wet (hence the name fresco, Italian for "wet"), the artist was effectively calcifying the colors "into" the surface of the wall rather than "on" it (Cennini, 1933; Constable, 1948).

Altarpieces were made out of wood-panels - several wood-panels combined in a "polypytch" in the early Renaissance; one large wood-panel or pala in the later Renaissance-or more rarely out of stone or ivory (Welch, 2000,68). The panels would be covered in several layers of gesso,

\footnotetext{
${ }^{9}$ About two-thirds of the commissions in our sample were for religiously-themed paintings.
} 
then gilded, painted over with egg-yolk- or oil-based colors, and finally encased in an expensive frame that could itself be covered in gold leaf (Welch, 2000, 108).

Renaissance paintings were complex commodities the making of which required the performance of a wide array of disparate tasks. First and foremost, the painter needed to conceive and design the final artwork. According to Renaissance art theory, design was central to a painting's artistic content and was one of the key avenues through which ingenio would be expressed. Design quality was a function of several factors. These included an artist's choice of which figures to depict, their number, the position of their bodies, as well as their relationship to each other, to inanimate objects, and to their environment. Design also needed to express "a clear conception of the idea underlying whatever he [the artist] was depicting" (Bondanella and Bondanella, 1998, xi). According to Vasari, a sense for beautiful designs and compositions were just as (if not more) important to the art of painting than the ability to draw figures, objects, and backgrounds:

$[\mathrm{P}]$ ainting does not consist entirely in creating naked men, [...] among painters who have reached perfection can be numbered those who know how to express the imaginative composition of their scenes with skill and facility and their fantasies with sound judgment, and who in composing their scenes know how to avoid confusing them with too few and organize them in a creative and orderly way; and that kind of a painter can be called a talented and judicious artist. ${ }^{10}$

Alongside a good design, an artist's work needed to show grazia: a painting "[should] not reveal itself to be art and [should be] produced effortlessly and without obvious signs of study and emphasis upon technique" (Bondanella and Bondanella, 1998, xii). A painting of such perfect grace would be perceived not as the result of human design and effort, but of Nature herself. Last but not least, to be recognized as a true artistic achievement, a painting needed to express the emotional status of its main figures through their facial expressions and body language and similarly generate the desired emotional reaction on the part of the viewer. The emphasis on the transmission of emotional states was a key innovation that separated Giotto's work and that of his followers from the art of his predecessors (Vasari, 1998, 52). Their ability to represent and convey emotions was also what allowed Raphael's and Michelangelo's to "rise up and reach complete perfection" in the art of painting (Vasari, 1998, 277, 327).

Designing a painting was a demanding and time-consuming job (Vasari, 1998, 472, 490). A master had to come up with an original idea and composition. He had to decide what figures, and how many of them, to include in the painting, what background to use, what facial expressions to give them and how to position their bodies. They had to decide which figures to put in the

\footnotetext{
${ }^{10}$ Vasari $(1998,332)$.
} 
foreground and which in the background. Of key importance, they had to plan the emotional states of all major figures and how to best render them in practice. This step required the making of several preparatory drawings as well as "studies" or detailed renditions of each figure and object, and alternative versions of all of them. Once completed, these studies were combined together according to the painter's design and used to make a full-sized drawing of the final painting, or "cartoon."

Besides these more artistic tasks, making a painting consisted of a wide array of mundane jobs. In his guide to aspiring young painters, Cennini (1933) lists dozens of tasks and techniques that may be necessary to the production of even the simplest of paintings. Before a design could be transferred on a surface (that of a wall in the case of frescoes, that of a wooden table in the case of altarpieces), the latter had to be prepared by applying one or more layers of gesso. The gesso itself - or, more accurately, different types of gesso-had the be made. In the case of an altarpiece, a wood-panel of the right size also was to be produced. Having transferred the cartoon on the carefully-prepared surface, gold leaf would be applied if and where required, after which the painting proper could finally start. However the paint for several colors had to be made, as did all other materials that went into the production of the final work (including gold leaf, glue, and so forth). Once the painting had been completed, and the final touches had been made, an altarpiece was adorned with a frame and then transported to its final destination where it will be mounted on an altar or a wall, the last step before ownership was officially transferred to the patron.

Demand for a painter's services was a function his style and reputation for high-quality work (O'Malley, 2013, 27). As their reputation grew, painters were offered more and better-paying commissions from throughout the Italian peninsula (O'Malley, 2013, 3). They responded by hiring skilled and unskilled workers and setting up a bottega, or workshop, to aid them in the fulfillment of these commissions (Thomas, 1995, 76). The size of the bottega was a function of the volume of demand (Diorio, 2013, 223). Thus, early in his career an artist may have one or two assistant working for him, but employ five or six and perhaps more as he had established himself as a master painter (O'Malley, 2013, 160-5). Setting up a bottega empowered the painter to work on several commissions, even dozens of them, at once (O'Malley, 2013, 87). The making of Renaissance art was thus the result of team production. This fact was public knowledge at the time and patrons were well aware that the final product was not in any sense just the result of the painter's efforts. Indeed, the very concept of "autograph work did not exist in the Renaissance" (O'Malley, 2005, 73). However, the expectation remained that the painter would be heavily involved in the making of the painting from start to finish.

Much of the work to produce a Renaissance painting happened in the master's bottega. Here, he worked alongside his assistants as well as figures like garzoni - experienced manual workers- 
and fattorini - less experienced and usually younger manual workers assigned to the performance of menial tasks. Most workshops also had one or two discepoli, very young men - as young as thirteen years old-who had joined to learn from the master in the hope of becoming one themselves. Assistants, garzoni, and fattorini were waged workers, compensated by the master painter out of the commission money. The more experienced among the assistants may get some extra income by obtaining their own commissions. However they had to pay a cut to their masters if a commission had been fulfilled using any of the tools or materials from his bottega (Thomas, 1995, 76-77). Discepoli seldom received any monetary payment at all. In some cases, it was the discepolo-or rather his father - who paid the master for the opportunity to serve in his workshop (Comanducci, 2000, 44). However, they lived rent-free in the master's home, eating and sleeping alongside his family.

If the demand side of the Renaissance market for paintings was competitive - with patrons outbidding each other for the services of the most skilful artists - so was the supply side (Etro and Pagani, 2012; Etro, 2018). Competition was especially fierce at the local level (Welch, 2000, 91), but by the fourteenth century there already existed a national market for paintings in Italy. Although they were nominally required to join a guild and abide to its rules - in Florence painters traditionally belonged to the Arte dei Medici e Speziali, the guild of physicians and pharmacists (Nethersole, 2019, 67) - in fact, artists operated quite freely from guild interference in matters of price, employment, and quality insurance (Goldthwaite, 2009, 344).

The fundamental institution bringing demand and supply in the market for Renaissance paintings was the commission, or "allogazione." A potential buyer (e.g., a professional association, religious order, local government, or wealthy family) would solicit recommendations from merchants and other experts for the names more or less accomplished artists that could deliver a product of the expected quality. The final choice would depend on several considerations, including the the patron's budget and stylistic preferences, the scope of the artwork, its themes, and so forth (Baxandall et al., 1988). Once the patron had found a good match, the two would write down a contract stipulating some general obligations for both sides - time of delivery, type of artwork, range and timing of the compensation - but still leaving the artist significant creative freedom. A contract may specify that the artist was to produce an altarpiece representing a Madonna with Child with two Saints by her side, but the artist had some degree of autonomy in choosing how to represent the Virgin Mary and the Infant, which Saints to depict by their side, and from which episode of their lives. In many cases, the contract would not even specify the subject at all, although the artist was expected to follow tradition somewhat in his choices (O'Malley, 2005). Contracts for Renaissance paintings had to overcome the obstacle posed by the qualitative and subjective nature of art (Caves, 2000, 2006). Contracting parties mitigated this issue by tying compensation to some measurable properties of the painting that was expected to 
correlate with the artist' effort. Thus, larger paintings and paintings containing many figures sold at a premium (Etro and Pagani, 2012).

\section{Making Renaissance paintings: A simple model}

A Renaissance painting was a complex commodity. Producing it required that someone first conceptualize the the finished product in order to guide its execution. The ultimate quality of the painting would depend on both conceptualization and execution. To produce a masterpiece, both had to be of the highest quality. A beautiful conceptualization required the input of someone with ingenio - the painter - , a masterful execution that of someone with arte - the artisan (O'Malley, 2013, 73).

Given the large number of tasks that were necessary for the production of a Renaissance painting, one would expect that comparative advantage over each task would be distributed across a number of individuals. For instance, Renaissance painters and art theorists believed that ingenio and artistic talent were innate: Some where born with a lot of both, some with little or none. Vasari's accounts of the lives of the period's major painters is full of anecdotes of young artists doodling thoughtlessly only to have their superior abilities discovered by a passerby who happened to be an artist himself (Vasari, 1998). In other cases, it was the parents or family friends - also, in some occasions, professional painters - who became aware of a child's potential. Even among these talented artists, most excelled in only one or at best a few of the skills that went into the making of a beautiful painting. For example, Giulio Romano excelled at drawing and composition but his choices of color and execution were less than ideal (Vasari, 1998, 363). On the other hand, the people of his time saw Michelangelo as exceptional due to his unprecedented command of all of these skills, which made him superior to all other painters (Vasari, 1998, 42).

In a world without information costs, we should expect those few members of the population with exceptional artistic talent and ingenio to specialize in the supply of designs and compositions while leaving others all the disparate tasks that make up the execution of a painting. In reality, master painters seldom performed only the most conceptual of tasks. Rather, they were also heavily involved in the execution of their paintings, including tasks that were entirely unrelated to their comparative advantage, even ones that required no artistic talent at all. For instance, Renaissance painters were always also business-owners and entrepreneurs. As such, they were responsible for the soliciting of commissions and the bargaining over contractual terms. They would also monitor and direct the efforts of some of the workers involved in the execution of the painting. Other tasks they assigned to independent contractors, whose efforts they could neither monitor nor direct. 
This section develops a simple model of the production of a Renaissance painting. The purpose of this exercise is not strictly theoretical, but rather to motivate our discussion of the historical evidence in the following section. To this end, we structure our model to speak to three critical choices about the organization of the production of paintings. First, who should own the bottega, or the painting-making firm? ${ }^{11}$ Second, which tasks should be performed within the bottega, under the direct supervision of the owner? Which tasks, if any, should be performed by independent contractors, specialized artisans like carpenters and gilders? Finally, we ask who, within the bottega, should perform which task. Should master painters, for instance, focus entirely on those activities over which they have a comparative advantage, and leave all other tasks to their employees? Or should they perform some other, more menial tasks, out of the concern that their employees cannot be trusted to perform them effectively?

\subsection{Environment}

Consider the case of a market populated by two types of workers: Painters and Artisans. These workers have utility functions of the form:

$$
U_{i}=w_{t}-\gamma_{t, i} e_{t, i}
$$

where $i \in(P, A)$ and $P$ stands for painter and $A$ for artisan. $w_{t}$ represents a worker's income, $e_{t, i}$ the effort supplied in the performance of task $t \in(c, \mu)$, and $\gamma_{t, i}$ is a shift parameter measuring $i$ 's disutility of effort from the performance of task $t$. Painters have a comparative advantage in the performance of the creative task $c$ while Artisans enjoy a comparative advantage in the performance of the mundane task $\mu$. We express these as differences in the two types' disutility of effort in the respective tasks. So, $\gamma_{c, P}<\gamma_{c, A}$ and $\gamma_{\mu, A}<\gamma_{\mu, P}$. Furthermore $\kappa_{t, i}>1$ measures a worker $i$ 's degree of comparative advantage in the performance of task $t$ over another worker, such that $\gamma_{c, A}=\kappa_{c, P} \gamma_{c, P}>\gamma_{c, P}$ and $\gamma_{\mu, P}=\kappa_{\mu, A} \gamma_{\mu, A}>\gamma_{\mu, A}$.

Both tasks, $c$ and $\mu$, are necessary for the production of a painting by a bottega. Thus, the bottega production function for a painting of quality $Q$ looks as follows:

$$
Q\left(e_{c}, e_{\mu}\right)=\min \left(\frac{1}{\alpha} e_{c}, \frac{1}{\beta} e_{\mu}\right)
$$

where $\beta>\alpha$ indicates that the marginal product of the creative task exceeds that of the mundane one. The Leontief functional form captures the essential fact that producing a painting required

\footnotetext{
${ }^{11}$ Ownership, in this context, corresponds to both residual claimancy over the profits of the firm as well as the ability to direct and monitor the performance of the firm's employees.
} 
the performance of both tasks. ${ }^{12}$ We further assume that only one individual can perform either task. Thus, if the painter supplies any effort towards the performance of $c$, the artisan cannot also perform $c$. Vice-versa, if the artisan supplies any effort towards the performance of $\mu$, the painter may not perform $\mu .{ }^{13}$ Once produced, the painting is sold in the primary market where revenues from its sale are linear in quality and the price per unit of quality is normalized to 1 :

$$
R=Q\left(e_{c}, e_{\mu}\right)
$$

If employed by the bottega to perform task $t$, worker $i$ may choose to supply a high — $e_{t, i}^{H}$ - or low- $e_{t, i}^{L}$-level of effort. The worker's choice of effort is hidden unless the bottega incurs a fixed monitoring cost $\Theta_{t}$, which perfectly reveals it. The bottega offers the worker the following contract: A wage $w_{t}^{H}$ if the worker supplies $e_{t, i}^{H}$ or a wage $w_{t}^{L}$ if the worker supplies $e_{t, i}^{L}$, where the bottega sets the two wages such that

$$
w_{t}^{H}-\gamma_{t, i} e_{t, i}^{H}>w_{t}^{L}-\gamma_{t, i} e_{t, i}^{L}{ }^{14}
$$

For the bottega to find this contract worth introducing, profits with monitoring must exceed profits without monitoring. For example, if the worker being monitored is the artisan, monitoring the latter's effort is profitable as long as

$$
\frac{1}{\beta} e_{\mu, A}^{H}-w_{\mu}^{H}-\Theta_{\mu}>\frac{1}{\beta} e_{\mu, A}^{L}-w_{\mu}^{L} .
$$

Which implies that $\Theta_{\mu}$ must not exceed $\frac{1}{\beta}\left(e_{\mu, A}^{H}-e_{\mu, A}^{L}\right)+w_{\mu}^{L}-w_{\mu}^{H} \cdot{ }^{15}$

\subsection{Optimal ownership}

So far we assumed the existence of a bottega employing and monitoring workers. In reality such a firm had to be started, owned, an managed by somebody. We focus on the choice between a painter-owned and an artisan-owned bottega. In the former case, the painter hires the artisan, directs and monitors the latter's efforts, and exercises residual claimancy over the receipts of the bottega. The roles are reversed if the artisan owns the business. Due to the hidden nature of effort, the choice between these two arrangements becomes a crucial one and will depend on which one generates the most profits.

\footnotetext{
${ }^{12}$ We thank Doug Allen for suggesting the use of a Leontief production function in this context.

${ }^{13}$ As we explore below, either worker may however perform both tasks.

${ }^{14}$ Of course $w_{t}^{H}-\gamma_{t, i}$ must also exceed the utility derived from income available to worker $i$ outside of the bottega.

${ }^{15}$ Reversely, if the worker being monitored is the painter, monitoring is only profitable if $\Theta_{c}<\frac{1}{\alpha}\left(e_{c, P}^{H}-e_{c, P}^{L}\right)+$ $w_{c}^{L}-w_{c}^{H}$.
} 
Consider the case of painter-ownership first. If the bottega is owned by the painter, the latter will not want to shirk in the performance of the creative task $c$. The painter-owner wishes to maximize the profits of the bottega, which are given by:

$$
\Pi_{P}=\min \left(\frac{1}{\alpha} e_{c, P}^{H}, \frac{1}{\beta} e_{\mu, A}^{H}\right)-\Theta_{\mu}-w_{\mu}^{H}-\gamma_{c, P} e_{c, P}^{H}
$$

where $e_{c, P}^{H}$ is the painter's optimal level of effort in the performance of the creative task, $e_{\mu, A}$ is the artisan's optimal effort in the performance of the mundane task, $w_{\mu}^{H}$ is the wage the painter promises to the artisan if the latter supplies effort $e_{\mu, P}^{H}$, and $\Theta_{\mu}$ is the cost of monitoring task $\mu$.

On the other hand, if the artisan assumes ownership of the firm instead, the profit function being maximized is given by:

$$
\Pi_{A}=\min \left(\frac{1}{\alpha} e_{c, P}^{H}, \frac{1}{\beta} e_{\mu, A}^{H}\right)-\Theta_{c}-w_{c}^{H}-\gamma_{\mu, A} e_{\mu, A}^{H}
$$

where as above $e_{\mu, A}^{H}$ is the artisan's optimal level of effort in the performance of the mundane task and $e_{c, P}^{H}$ is the artist's optimal effort in the performance of the creative task. $w_{c}^{H}$ is the wage the artisan promises to the painter if the latter supplies effort $e_{c, P}^{H}$ and $\Theta_{c}$ is the cost the artisan must incur to task $c$.

Whether the painter or the artisan will assume ownership of the bottega depends on which, between $\Pi_{P}$ and $\Pi_{A}$ is larger.

Proposition 1: The painter owns the bottega when the cost of monitoring the creative task, $\Theta_{c}$, exceeds some threshold level $\bar{\Theta}_{c}{ }^{16}$

Two reasons suggest that the cost of delegating the creative task- $\Theta_{c}-$ will tend to exceed $\bar{\Theta}_{c}$ and be significantly larger than the cost of delegating the mundane task $-\Theta_{\mu}$. First of all, creative tasks like the one performed by a master painter tend to be hard to monitor. One cannot easily establish the amount of effort that went into the design and planning of the design and composition of an artwork, since most of it takes place inside of the artist's head. For instance, the number of hours spent (nominally) on such tasks may or may not be correlated with a higher overall quality of the artist's contribution — what if, for instance, they were actually spent daydreaming, worrying about some personal issue, or planning a different painting? This issue is well illustrated by an episode from Leonardo da Vinci's life. When he was working on the Last Supper in the Dominican convent of Santa Maria delle Grazie, the convent's prior was growing increasingly suspicious of Leonardo's work ethic and commitment:

\footnotetext{
${ }^{16}$ The proofs of all three propositions are straightforward and available from the author upon request.
} 
[It] seemed strange to him to see how Leonardo sometimes passed half a day at a time lost in thought, and he would have preferred Leonardo, just like the laborers hoeing in the garden, never to have laid down his brush. ${ }^{17}$

The duke of Milan had to intervene to explain to the prior that

the greatest geniuses sometimes accomplish more when they work less, since they are searching for inventions in their minds, and forming those perfect ideas which their hands then express and reproduce from what they previously conceived with their intellect. ${ }^{18}$

Second, the execution of a painting requires that its composition and design (i.e., the way the painting is ultimately supposed to look) be communicated by the painter to the artisan. This introduces an asymmetry between the painter-owned and the artisan-owned firms. The painter knows the quality of his contribution to the artwork and can thus more easily direct and monitor its execution by the artisan. The reverse is not true. The artisan may require the painter to describe his vision in detail before beginning execution, for instance by writing it down or providing a sketch. Even so, he may not realize fully how well-crafted the design is until further down the process. Things would get even more complicated if the plan for the painting needs to be adjusted (as it was often the case) as the painter discovers flaws in the original design during the execution.

\subsection{Optimal allocation of tasks and the limits of the bottega}

Having taken up ownership of the bottega, the painter must now choose whom to allocate the performance of the mundane task $\mu$. So far we took as given that the latter is performed by the artisan and that this artisan must work within the bottega. However, there are two further configurations available to the painter-owner. First, the painter may assign the performance of the mundane task to an artisan from outside the firm, i.e. an independent contractor. Second, the painter may also decide to forego the benefits of specialization altogether and perform the task directly.

The profits of the bottega under these three arrangements are as follows:

$$
\begin{aligned}
\Pi_{P}^{F} & =\min \left(\frac{1}{\alpha} e_{c, P}^{H}, \frac{1}{\beta} e_{\mu, A}^{H}\right)-\Theta_{\mu}^{F}-w_{\mu}^{H}-\gamma_{c, P} e_{c, P}^{H} \\
\Pi_{P}^{M} & =\min \left(\frac{1}{\alpha} e_{c, P}^{H}, \frac{1}{\beta} e_{\mu, A}^{H}\right)-\Theta_{\mu}^{M}-w_{\mu}^{H}-\gamma_{c, P} e_{c, P}^{H}
\end{aligned}
$$

\footnotetext{
${ }^{17}$ Vasari $(1998,290)$.

${ }^{18}$ Vasari $(1998,290)$.
} 


$$
\Pi_{P}^{S}=\min \left(\frac{1}{\alpha} e_{c, P}^{H}, \frac{1}{\beta} e_{c, P}^{H}\right)-\left[\gamma_{c, P} e_{c, P}^{H}+\gamma_{\mu, P} e_{\mu, P}^{H}\right]
$$

where $\Pi_{P}^{F}$ stands for the firm's profits when $\mu$ is performed by an artisan employed by the bottega, $\Pi_{P}^{M}$ represents the firm's profits when $\mu$ is entrusted to an independent contractor via the market, and $\Pi_{P}^{S}$ are the profits to a painter-owner who performs $\mu$ directly, or, to use the terminology of Barzel (1987), when the painter-owner "self-polices" the performance of $\mu$.

Proposition 2: The painter-owner delegates task $\mu$ to an independent contractor whenever the cost of delegation in the bottega exceeds that of delegation on the market, or $\Theta_{\mu}^{F}>\Theta_{\mu}^{M}$, and to an employee of the bottega otherwise.

The logic behind Proposition 2 is straightforward. ${ }^{19}$ If a job was performed within the bottega, the master had the ability to direct it and monitor it in realm time. For instance, in the painting of secondary sections, he could oversee his assistant's work and direct him to draw a figure in a certain way or to use a specific pigment and so forth. The same task could conceivably be performed by an external contractor, without the master's supervision. But the master would have done so only to the extent that he could easily evaluate the contractor's work upon completion, or in the case any mistakes (including honest ones) due to the lack of the master's direction could be fixed at a low cost. Neither of these conditions were met in our example of fresco painting. Frescoeing required that a proper technique be used to ensure that pigments would dry into the surface of a wall of ceiling. Otherwise, the painting would quickly deteriorate. Similarly, any mistake made in the execution of a fresco, whether due to honest misunderstanding or to lack of effort and carelessness in execution, would have caused significant losses to the master. In the case of a fresco, fixing errors and poor execution required that the entire section be frescoed again, which took time and other resources. Under these circumstances, Proposition 2 implies that the master will not entrust the execution of even secondary sections of a fresco to independent contractors, and the same logic applies to any task that manifests similar characteristics.

Proposition 3: The painter-owner self-polices the performance of the mundane task $\mu$ as the cost of doing so inside the firm - $\Theta_{\mu}^{F}$ - and on the market - $\Theta_{\mu}^{M}$-exceed the threshold values $\bar{\Theta}_{\mu}^{F}$ and $\bar{\Theta}_{\mu}^{M}$ respectively, where both $\bar{\Theta}_{\mu}^{F}$ and $\bar{\Theta}_{\mu}^{M}$ are increasing in the artisan's degree of comparative advantage over the painter in the performance of $\mu$, or $\kappa_{\mu, A}$.

Proposition 3 implies that the choice between delegation and self-policing depends on two factors. The first factor is the cost of delegation. Effort and other valuable resources must be

${ }^{19}$ This argument is akin to those made in the transaction cost economics literature on the choice between different forms of labor employment (Cheung, 1983; Allen and Lueck, 1992). 
put towards monitoring employees or evaluating the performance of an independent contractor. Painter-owners will find it more profitable to keep a task, even one for which they do not enjoy a comparative advantage, for themselves whenever these costs grow exceedingly large. This is the same logic behind the saying that "if you want a thing done well, do it yourself." Yet, the cost of delegation must be compared to the benefits that come from specialization. If the magnitude of the artisan's comparative advantage is very large, the painter-owners may decide to delegate even as this requires the sacrifice of significant resources.

\section{Evidence from the Italian Renaissance}

\subsection{Residual claimancy}

Evidence on residual claimancy over the production of Renaissance paintings comes from the text of commission contracts from this period. An analysis of seventy-six commissions shows that, in every single instance, the painter assumed residual claimancy over the final product vis-a-vis the patron. ${ }^{20}$ Thus, the painter's signature, not that of any of the other artisans who would have been involved in the production of the artwork, appeared on the document. Moreover, all contracts specify that compensation for the painting was to be made to the painter. In most cases, the sum was to cover the painter's services as well as the labor of his assistants and all other expenses, like the cost of pigments, gesso, gold leaf, scaffolding, wood panels, and so forth. For example, a commission from 1461 between the painter Benozzo Gozzoli and the Florentine Compagnia della Purificazione specifies that the former was to "do all this [producing the altarpiece] at his expenses" and that all expenditures had to come from the three-hundred lire that he was to receive for it. Out of fifty-two commission contracts in our data-set that mention explicitly which party was to pay for production expenses, similar formulas - allocating the burden to the painter-appear in forty-five of them.

In some instances, the patron may provide the artist with materials such as precious colors like ultramarine blue or gold leaf. For example, the Diocese of Siena in 1404 agreed to provide the painter Taddeo di Bartolo with "all provisions of gold and colors and anything else he may need, so that said Taddeo won't have to contribute anything other than the work of his brush." This practice was likely due to the fear that the painter may be tempted to purchase lower-quality alternatives and pocket any savings. In his guide to painting, Cennini (1933) discusses several techniques to imitate the effect of expensive materials like gold and ultramarine by using cheaper alternatives like tin and indigo.

None of the commissions in our data-set show any evidence that any other specialist beside

\footnotetext{
${ }^{20}$ Sources for all contracts are listed in the appendix.
} 
the painter was involved in the bargaining process or that there existed a separate contract between the patron and an artisan over the latter's contribution to the commission. The painter signing the commission was solely responsible for overseeing and compensating the contribution of everyone involved in the production process, from day-laborers to specialists like woodworkers and gilders (Thomas, 1995, 210-211).

By contract and custom, the artist was subjected to financial penalties if any element of the painting wasn't up to the agreed-upon standards of quality (O'Malley, 2005, 78). Thus, the artist alone borne all liability over the final product. For example, a commission contract from 1285 between the Sienese painter Duccio and the Florentine Compagnia di Santa Maria contains the following provision: If the Compagnia was not satisfied with the final product, Duccio was responsible for fixing any defects or would have had to return the one-hundred and fifty Florins he had paid. In some cases, the master may be held liable for all defects and damages for years following the delivery of the painting to the patron. For instance, a commission between Piero della Francesca and the Compagnia della Misericorda stipulates that "said Piero shall be obliged to restore at his own expense every blemish which the said picture may show in the course of time for the next ten years, on account either of the defect of the wood or of the said Piero."21

Another way commissions assigned liability to the artist was by leaving the size of the final compensation not fully specified. For instance, some contracts provided only a range for the payment to the painter, with the exact amount left to a panel the members of which where to be chosen by both parties. After having evaluated the final work, this panel would decide how much the painter was to be paid. Consider for instance the contract from 1442 between Priamo della Quercia and the Church of St. Michael in Volterra. The final compensation was "to be decided by two citizens of Volterra, one selected by [the patron] and one by said master Priamo." This sum was neither to exceed one-thousand and two-hundred lire nor fall short of one thousand lire. A similar formulation appears in the text of a commission between Baldassarre Estense and his patron Simone Ruffino. The two agreed to entrust a local artist named Cosimo Tura with evaluating the worth of the final product. If Tura was to find that the painter had done a truly exception work, Ruffino was obliged to pay Estense an extra ten gold ducats - on top of the onehundred and thirty specified in the commission. If, however, Tura found that the painting was of poor quality, it was Estense who had to return ten ducats to the patron. The commissioned artist may also suffer a financial penalty for late work. Thus, in 1466 Benozzo Gozzoli agreed to deliver an altarpiece to the city of San Gimignano within the next five months or to pay the latter double the price of the commission, or one-hundred and eighty lire.

Finally, masters bore the reputational consequences of their workshop's performance. A

${ }^{21}$ Similar provisions appear in three other contracts in our data-set. 
workshop's brand was among its most valuable assets. Producing masterpieces today could attract the attention of other patrons and open the door to more and possibly more remunerative commissions tomorrow (Thomas, 1995, 96-7). ${ }^{22}$ Vasari's Vite discusses several examples of artists receiving prestigious assignments following the production of a particularly well-received painting. In one case, Sienese painter Domenico Beccafumi was able to amass a stream of commissions in Pisa after a local government official had been impressed with some other paintings of his (Vasari, 1998, 390). We find evidence of the import of reputation in the text of some commission contracts as well. For example, Benozzo Gozzoli's 1461 commission required him to produce an altarpiece "in such a way that it exceeds all the good painting so far done by the said Benozzo, or at least equals it." ${ }^{23}$ A similar formulation appears in a commission from 1469 between Benedetto Bonfigli and the city of Perugia. The contract demanded that he produce "a painting of the same quality as the one that Bonfligli has made on another wall of the same chapel." These examples show that patrons considered a painter's past work before awarding a commission. If a good reputation accumulated over a series of well-received work could make a painter's career, a bad reputation due to sloppy or inconsistent work could ruin that of an established master. This was the case of Perugino, who developed a reputation for little creativity later in his career and had to leave Florence following the poor reception of one of his paintings (Vasari, 1998, 264-5).

Renaissance painters must have been keenly aware of the benefits of good reputation and the costs of a bad one. Cennini discusses this issue explicitly in his popular Handbook. To young artists tempted to cut costs to make an extra florin in the short run, he offered the following:

I give you this urgent advice, to make an effort to always embellish with fine gold and with good colors [...]. And if you wish to reply that a poor person cannot make an outlay, I answer that if you do your work well, and spend time on your jobs, and good colors, you will get such a reputation that a wealthy person will come to compensate you for the poor one; and your standing will be so good [...] that if a master is making one ducat for a figure you will be offered two; and you will end by gaining your ambition. As the old saying goes, good work, good pay. ${ }^{24}$

Virtually all - seventy-one out of seventy-six - of the commission contracts in our sample were awarded to a sole painter. Indeed, some of them explicitly stipulate that the commissioned artist could not subcontract the painting to another artist: a contract from 1445 between Piero della Francesca and the Confraternity of the Misericordia in San Sepolcro specified that "no other

\footnotetext{
${ }^{22}$ Reputation was often built over generations as many workshops, especially in Venice and Florence, were run as family businesses (Tietze, 1939, 34). See also related discussions in Thomas (1995) and Wackernagel (1981, 304). ${ }^{23}$ Chambers' translation of the original text (Chambers, 1970).

${ }^{24}$ Cennini $(1933,60)$.
} 
painter besides [Piero] could put his hand on the brush." A 1502 contract between Andrea Sansovino and the government of Florence uses a similar formulation: "And by vigour of their authority they [the government officials] have decided to commission from the said Andrea the image of the said Holy Saviour, to be done by his own hand and by no one else." 25

Some commissions, on the other hand, would make explicit mention of two or more painters. Only five contracts in our data-set identify at least two artists who were expected to contribute to the final painting. One reason patrons may hire multiple masters was to cut down on the time needed to complete a particularly large painting. Indeed, "partnerships were especially common for frescoes, since the large scale of this commissions required a significant outlay for materials and other resources" (Diorio, 2013, 188). Two of the thirty-one fresco commissions in our data-set were awarded to at least two painters. In the first instance, Pope Sistus IV commissioned the frescoing of the Sistine Chapel to four Florentine painters - Botticelli, Ghirlandaio, Perugino, and Cosimo di Lorenzo. ${ }^{26}$ The second instance was that of a commission from 1407 between the Diocese of Siena and the duo of Spinello Aretino and Martino di Bartolomeo. The text of the contract specifically indicated which sections of the Duomo each of the two was to paint.

One implication of our model is that commissions awarded to multiple artists are unlikely. This will be especially true if the patron cannot easily identify each of the artists' contributions. Indeed, projects involving several artists could run into serious problems. For example, in 1448, the Ovetari family commissioned a painting to two masters-Mantegna and Pizzolo. One year later, production had barely started due to a conflict between the two masters. A mediator had to be brought in to resolve the dispute and assign to each a specific portion of the fresco (Welch, 2000, 99). The benefit of this solution was that, by assigning a separate section of the work to each artist, it increased the patron's ability to tell one painter's contribution from all others'. This seems to have been the way the work had been divided between the masters awarded the commission for the Sistine Chapel (O'Malley, 2013). In another example, the text of the contract between the Diocese of Siena and the duo Aretino-di Bartolomeo, specifically indicated which sections of the Duomo each of the two was to paint. Even in the case of masters collaborating on an altarpiece, the standard practice was for each to work on a different panel, with the more experienced and reputable of them entrusted with the central, larger panel, and any other painter with the smaller side-panels (Constable, 1954, 10).

Another reason why two or more artists may appear on the same commission was the existence of a pre-existing partnership between them. Partnerships were not unusual, especially between young painters looking to share the costs of setting up business (Goldthwaite, 2009,

\footnotetext{
${ }^{25}$ Chambers' translation of the original (Chambers, 1970).

${ }^{26} \mathrm{~A}$ few years later, three of them received another major commission from Lorenzo de' Medici to paint the walls of the Palazzo della Signoria in Florence.
} 
359). ${ }^{27}$ However, partners were rarely on equal footing, with the most experienced of them taking a leading role in the fulfilment of commissions (Thomas, 1995, 207). Indeed, they did not always work on the same commissions at all and often "operated quite separately as individuals, receiving and carrying out commissions independently of the company" (Thomas, 1995, 13). However, the evidence suggests that, on occasion, artists did work together on a commission. Our data-set includes three instances of contracts awarded to partnerships of painters. For example, in 1490 the Franciscan friars from the town of Palco awarded the commission for an altarpiece to "Masters Davide and Domenico Ghirlandaio." ${ }^{28}$ However, the text also notes that "Domenico must diligently draw by [his] hand and colour all the heads." Just two years later, the Venetian School of San Marco awarded "our dear and most beloved brothers Messer Gentile Bellini ... and his peerless brother Messer Giovanni Bellini, in whose name the former also acts" the commission for a fresco. ${ }^{29}$

Interestingly, in both of these cases, the partners were brothers, meaning that two out of the three commissions awarded to partnerships in our sample were executed by individuals related to each other. This may suggest that partnerships may have been easier to manage between family members, who are likely to face lower levels of informational asymmetry and opportunism. Yet, we know from the experience of the painter Bicci di Lorenzo, that partnerships of this kind were not limited to artists who were related. Di Lorenzo was a popular painter of frescoes and, as such, he had much to gain from sharing the burden of the work with other masters. His strategy was to form partnerships with former apprentices and assistants who had worked in his workshop in the past. This allowed him to handle an impressive mole of work: In 1433, (Diorio, 2013, 188) reports, he took on six separate commissions for fresco paintings. The receipts from these partnerships were divided among the participating artists on unequal terms. For instance, the text of a partnership contract between di Lorenzo and Stefano d'Antonio stipulated that the former was to receive fifty-eight percent of all revenues from their cooperation, while d"Antonio was to receive the remaining forty-two percent. The two artists further agreed to share all expenses equally. ${ }^{30}$

\subsection{Division of labor}

Executing a painting required the performance of a long list of tasks. Cennini's Handbook gives us a sense of the magnitude of this exercise. In it, he lists dozens of tasks that would be necessary to produce even the simplest of paintings. For an altarpiece, someone had to come up with design and a composition. Studies had to be made for all major figures and objects as well as the background. These studies had to be used to produce a full-sized cartoon, which in turn would

\footnotetext{
${ }^{27}$ See also Diorio $(2013,187)$.

${ }^{28}$ Chambers' translation of the original (Chambers, 1970).

${ }^{29}$ Chambers' translation of the original (Chambers, 1970).

${ }^{30}$ The contract is quoted by Diorio $(2013,90)$.
} 
have been employed to transfer the design on the surface of the panel. The panel itself had to be prepared. One had to make the glue to piece together smaller panels and cover them in several layers of gesso. Before the actual painting process could start, someone needed to produce the different colors by grinding raw materials like minerals and plants. Also, the gold leaf had to be "beaten" onto the gesso layers. Finally, the pigments had to be applied on the surface of the altarpiece. After the last fixes had been made, the panel could be encased in a frame that had been tailor-made for it. Some had then to take the altarpiece and transport it to its final destination, where it would be set up and arranged as necessary.

Given the large number and varying nature of these tasks, the benefits of the division of labor and specialization would have been substantial. One such benefit came in the form of quicker turnaround. If one artist were to perform all of these tasks alone, it would have taken him a long time to complete any one commission. Dividing up the tasks across several people would have allowed one to speed up the process and handle more commissions, perhaps even more than one at any point in time. Indeed, according to (Tietze, 1939, 45), the emergence of the workshop "increased the painter's scope, augmented their effectiveness and afforded opportunities for trying out on a larger scale of artistic principles which in reality were their personal property." Two other advantages of specialization are the classic Smithian and Ricardian effects: By specializing in different tasks, people may get better at each as well as exploit natural or acquired comparative advantages. A workshop's paintings may end up being of higher quality if the master is able to focus entirely on issues of design and composition and leave the grinding of colors and perhaps even some of the painting to others. The lure of delegation would only increase with a painter's success and growing reputation. The more offers he received, the greater the incentive to delegate.

One key intuition of our model is that specialization comes at a cost because resources must be invested to ensure that everyone involved contributes some minimum level of effort in the performance of their tasks. ${ }^{31}$ Thus, the model points to the trade-off between the benefits and costs of specialization as key to understand the organization of the production of Renaissance art.

"The experience of some of the most celebrated masters of this period illustrates both sides of this trade-off. At one end of the spectrum was Pietro Perugino. Perugino's paintings were extremely popular with his contemporaries. He was active in Florence and Perugia, where he operated two workshops, but was also awarded prestigious commissions in Rome, including for sections of the Sistine Chapel. In order to accommodate the high volume of demand that he was receiving, later in his career Perugino relied increasingly on the delegation of tasks to his many assistants. However, in order to minimize the possibility of poor execution, he was forced to to mechanize the production process to the maximum extent. For example, he would employ the

${ }^{31}$ This point has been previously explored by Stigler (1951), Barzel (1987), Becker and Murphy (1992), and Allen and Lueck (1998). 
exact same same design and composition for multiple commissions. In the words of (Vasari, 1998, 264), "[Perugino had] reduced the theory of his craft to such a fixed style that he executed all his figures with the same expression." While this strategy resulted in lower costs of delegation and overall consistency in the product of his workshop (Shearman, 1983, 44), it ultimately costed him his reputation in Florence:

It is said that when [his latest] work was uncovered, it was very harshly attacked by all the young artisans, most especially because Pietro [Perugino] had re-used figures which he had placed in his works on other occasions, and even his own friends, questioning him, said that he had not taken sufficient pains and had neglected the good method of working, either out of avarice or out of a desire to save time.

According to (O’Malley, 2013, 140, 182), Perugino never received another commission in Florence following this debacle.

At the other end of the spectrum, illustrating the costs of non-delegation, is the experience of Michelangelo. Having rapidly established himself as the greatest painter of his generation, Michelangelo's services were in high demand all over Italy. The Popes seem to have been particularly fond of his work, and for that reason he spent long stretches of time in Rome, frescoeing the papal palace and its chapels. The one aspect of Michelangelo's performance the Popes were not particularly fond of was the long time it would take him to complete a commission. Michelangelo's perfectionism led him to forego any assistance in the execution of his paintings. Thus, while working on the Sistine Chapel, he elected to perform directly virtually every task, including the time-consuming one of grinding his colors. Unsurprisingly, this slowed him down significantly, prompting the Pope to reprimand Michelangelo, who-according to Vasari - defended his methods by arguing that the fresco would be completed only "when it satisfies me in its artistic details." It took Michelangelo almost two years to finish that work (Vasari, 1998, 442).

The historical evidence shows that the modal painter's workshop fell somewhere in between these two extremes. Masters performed some key tasks but entrusted many - though not all — of the most mundane ones to their assistants working in the bottega. Thus, according to one art historian:

For the production of most great art works and artistic complexities, it was [...] largely a question of a multimembered working collective. The head of the workshop might at best give it his stamp by force of his personal supervision and efficiency of execution, without $[. .$.$] keeping every detail of the execution in his own hands. Such division of$ labor was occasioned and made indispensable by the particularly laborious execution 
procedures for painting $[\ldots]$ with the many, in part purely technical preparatory and subsidiary tasks they involved. ${ }^{32}$

Finally, for some highly-specialized tasks, they relied on independent contractors.

\subsubsection{Sua mano: Tasks performed by the artist}

The painter-owner's key responsibility was to develop a painting's design, style, and composition (Wackernagel, 1981, 311): "Because design was the backbone of style, defining each man's individuality, painters maintained strict control of their design process" (O'Malley, 2013, 127). This was "a task that could not be delegated" (O’Malley, 2013, 132). In developing his design, the painter spent many hours drawing the "general concept of the image," or embrione, as well as several studies "of individual figures and figures in relationship" (O'Malley, 2013, 127). Having developed the general design for the painting, he would move to "mak[ing] close studies of individual heads" (O’Malley, 2013, 128) and finally "[integrated] these studies on a single sheet, in preparation for visualizing and transferring the complete design [onto the surface of the medium]" (O'Malley, 2013, 128).

The emphasis on ingenio and design one finds in Vasari is consistent with this claim. As we mention above, Vasari saw the ability to conceive beautiful, proportionate, and balanced compositions as just as important as that of drawing on paper or painting on wood panels. According to him, key to the superiority of da Vinci, Raphael, and Michelangelo over their predecessors was their greater commitment the preparatory work - the sketching of different versions of the painting to strike the perfect balance between its elements, the studies of the heads and bodies of the main figures (Vasari, 1998, 277-8). For instance, in getting ready to paint his Last Supper, da Vinci made between one-hundred and fifty and two-hundred studies and preparatory drawings (Shearman, 1983, 42). For this reason, (Shearman, 1983, 42) characterizes this generation of artists as having developed a more "analytical" approach than previous ones: "This shift affected the appearance of works of the High Renaissance in two crucial senses: It contributed an unprecedented degree of novelty to each work and, apparently paradoxically, it contributed a great feeling of resolution or deliberation."

Another task masters reserved for themselves was the execution of the most significant sections of a painting. Evidence on the scope of artists' involvement in the execution of their commissions can be found in several sources. First, we know from Cennini's Handbook that knowledge of painting techniques was crucial to an artist's education. Second, modern art historians are often able to attribute whole paintings and even different sections of a single painting to different hands. Thus, according to (O'Malley, 2005, 20) the evidence suggests that "most painters

\footnotetext{
${ }^{32}$ Wackernagel $(1981,311)$.
} 
undoubtedly produced in their workshops most of the painting for which they were hired; that was their business." However, it is also clear that other hands were involved in the execution of most works of art (O'Malley, 2005, 70). Consistent with the implications of our model, masters generally undertook the painting of those sections that most closely embodied their vision of the completed work. These were the same sections - like the faces of all major figures - that were meant to stimulate an observer's emotional response (Berenson, 1980). For example, Shearman (1983, 47) describes Raphael's philosophy in managing his workshop as follows: "the inventions [i.e., the design and composition of the painting] should be his. [...] At some later point, he could subcontract or delegate some of the definitive work to an assistant."

More evidence on the scope of artists' involvement in the execution of their paintings comes from the text of commission contracts. For instance, these often specified the exact number of these figures. According to Etro and Pagani (2012) this was a mechanism developed to monitor the degree of an artist's contribution. Many contracts commented explicitly on the expected involvement of the commissioned painter. Consider for example the text of a commission from 1500 between Luca Signorelli and the Opera del Duomo in Orvieto, which stated that "master Luca is required to draw and paint sua mano [i.e., by his own hand] the aforementioned work." In 1502, the Archbishop of Siena awarded Bernardino di Betto, or Pinturicchio, a commission for a fresco which "obliged [Pinturicchio] to do all the designs of the stories in his own hand on cartoon and on the wall; to do all the heads all in fresco by his own hand, and to touch up in secco and finish them to perfection." ${ }^{33}$ The same sua mano provision — or one of the many variants in Latin and local dialects - appears in twenty-two contracts from our data-set.

The public meaning of this provision evolved over time (O'Malley, 2005, 70). Originally, the phrase referred to an artist's responsibility to oversee the making of the piece in his workshop. It did not imply that the individual artist was to complete the painting entirely on his own. However, by the fifteenth century, it had taken on the more precise meaning that, by accepting the commission, the artist was guaranteeing that he would be directly executing all of its most important sections. Thus, for instance, a commission from 1521 between Perugino and the Canons of Santa Maria Maggiore in Spello specifies that "the prescribed figures, landscapes, and adornments are all to be done by his [Perugino's] own hand according to the usage of a good master [...] the figures to be in his own hand, the adornment at his pleasure." 34 Another commission, also involving Perugino, required him "to paint manu propria all groups of figures and the faces of the most important ones." The text of the commission also noted that "that no painting will take place at all without his direct supervision." We find an even more explicit reference to a master's specific contribution to the painting in a contract from 1490 between Domenico Ghirlandaio and the Franciscan friars

\footnotetext{
${ }^{33}$ Chambers' translation of the original (Chambers, 1970).
}

${ }^{34}$ Chambers' translation of the original (Chambers, 1970). 
from the town of Palco. Here Domenico "agreed to be responsible for designing the figures of the saints in the altarpiece and for painting at least their heads" 35

One interpretation of the evolution of the meaning of the sua mano provision is that the need to specify masters' contribution to their paintings rose as the volume of commissions increased during the fifteenth century. Patrons may have realized that painters would be tempted by the possibility of accepting multiple commissions at once and only marginally aid in the making of each, leaving most of the work to their assistants. While enforcing the sua mano clause may have been tricky, a master who disregarded it too cavalierly was bound to be caught and incur penalties. For instance, an unsatisfied patron may appeal to the clause that allowed him to have the painting evaluated by a panel of experts with the power to lower the compensation of the master (Wackernagel, 1981, 344). The identification of a painter's contribution was facilitated by the fact that, in most instances, previous works of his were available and known to all parties involved and by the fact that each painter, especially among the most established ones, developed a distinctive style (Baxandall et al., 1988). Reliance on one's assistants for key sections of a painting may also result in reputational losses. For example, Shearman (1983) reports the experience from early in Raphael's career, who he had been commissioned by the Papacy to paint several rooms of the Vatican palace. When it came to the third of these rooms, he entrusted significant portions of the fresco to his assistants leading to catastrophic results (Shearman, 1983, 52). In particular, the section of the fresco representing The Oath of Leo III has been described as "a composite of some half-understood recollection of Raphael's works. [...] If the unhappy results of excessive uncontrolled delegation are clear to us, they were surely clear to Raphael, and it never happened again" (Shearman, 1983, 52).

Finally, the artist was responsible for the performance of tasks for which no particular artistic talent was necessary. The most egregious case was the expectation that the master accompany the finished product - when this had not been made "on site," as was the case with frescoes - and oversee the instalment in its final destination. Altarpieces were very delicate objects and even the smallest degree of carelessness could compromise their structural integrity. For instance, Florentine painter Neri di Bicci recorded the case of an altarpiece that had broken into small pieces while being transported on horseback even though "[it] was packed between a pair of baskets" for protection. ${ }^{36}$ The larger, more complex, and therefore more fragile the artwork, the more likely it was for the master to personally deliver it to the patron (Thomas, 1995, 199). Thus, contracts often referred to this task as one to be taken on by the painter. For instance, the contract from 1308 awarding Duccio the painting of an altarpiece for the Cathedral of his native Siena specifies that the master himself was to "place [it] on top of the main altar of the Church of Saint Mary in

\footnotetext{
${ }^{35}$ The second Perugino commission and the Ghirlandaio are quoted in O'Malley $(2005,73)$. The author's translation.
} ${ }^{36}$ Thomas $(1995,199)$. 
Siena." Similarly, a commission from 1523 between Lorenzo Lotto and the Confraternity of Saint Lucy in Jesi contains the following passage: "And said Master Lorenzo is bound to take the aforementioned pala [i.e., the altarpiece] to the city of Jesi and place it in the chapel of said friars." The texts of twelve commissions in our sample make mention of this not-quite-artistic requirement. Master painters had no clear comparative advantage in this task and could have hired a merchant to take the artwork to its destination. ${ }^{37}$ The transportation and installation of the painting was simply too dangerous to be left to third parties because it was impossible for the artist to make sure that the painting was being handled with the necessary care during transit and the risk of compromising it was too high.

\subsubsection{Tasks performed in the bottega}

Central as the artist my have been to the process, "Renaissance painting was a collaborative business" (O’Malley, 2005, 71). Even da Vinci and Michelangelo, who were reluctant to involve assistants in the execution of their commissions, relied on them often during the preparatory stage (Shearman, 1983, 44). Masters would hire a variety of more or less specialized workers to aid them in the execution of commissions and who "performed [their tasks] under the supervision of the painter who signed the contract" (O’Malley, 2005, 66). Employees of a workshop-assistants, fattorini, and garzoni - were strictly prohibited from subcontracting to outsiders the jobs the master had assigned to them (Comanducci, 2000, 49).

An artist-owner will entrust a task to his employees when its performance necessitates the master's direction to ensure consistency with his plan for the final painting. Supervision of certain tasks was essential to produce art such that "ideally, the contribution of the assistant and that of the master were completely integrated and indistinguishable" (Comanducci, 2000, 49). ${ }^{38}$ Our model predicts that these assistants will not assume residual claimancy over the product of their collaborative efforts. Information from Neri di Bicci's Ricordanze - an account of over twenty years of a painter's business activities in fifteenth century Florence corroborates this prediction. Di Bicci's records show that he employed twenty-two assistants between 1453 and 1474. Of them, most remained in his employment for at least a year. All wages were negotiated individually at the beginning of each year and there was significant variation in their value between assistants. For instance, in 1466 di Bicci's highest paid employee made almost ten times as much as the least paid one. Moreover, remuneration appears to have been a function of experience, as the former had been working for the master for over six years while the latter had just joined the

\footnotetext{
${ }^{37}$ Late medieval and Renaissance Europe had already a developed system for the transportation of commodities by water, including rivers, but also by land Hunt et al. (1999). For instance, according to Hunt et al. (1999, 147), "by the end of the fifteenth century there were 60,000 mules per year plying the roads between Genoa and Milan."

${ }^{38}$ The author's translation.
} 
bottega. $^{39}$ The text of a labor contract for a bottega worker can be found in (Vasari, 1998, 338). This documents the beginning of Michelangelo's apprenticeship in the workshop of the Ghirlandaio brothers. The text mentions the wage Michelangelo was to receive for his services, the duration of the employment, and the requirement that he "do whatever the above-mentioned [Ghirlandaio brothers] may order him to do."

Quantitative evidence on the division of labor within Renaissance painters' botteghe is scant. However, the consensus among art historians is that employees' involvement in the execution of commissions was significant. The workshop participated in virtually every stage of production. During the preparatory phase, the assistants would "copy rough sketches, keep records of drawings, and make life studies" (Shearman, 1983, 49). They prepared the surface of the painting and laid several coats of gesso on the medium of choice. In the case of an altarpiece, they would also glue together separate panels (Thomas, 1995, 156). Glue, which was used in the making of altarpieces to secure the wood-panels to each other and to the frame, was also produced in the workshop from animal remains purchased from local butchers (Thomas, 1995, 153). Multiple sources agree that the making of colors - the grinding of the raw materials and mixing of the resulting powder with oil, water, or egg yolk to make a usable paint — was a key responsibility of a master's assistants. ${ }^{40}$ Even though this job could be very costly and time consuming, Cennini (1933) recommended the that masters refrain from purchasing ready-made colors from third parties due to the fact that merchants would often mix these with cheaper materials (Thomas, 1995). ${ }^{41}$ Finally, the most experienced and capable members of the bottega - and the assistants and discepoli in particularwill often contribute to the execution of the painting. This included transferring the cartoon prepared by the master onto the surface of the wall or of the wooden panel (Diorio, 2013, 54). It also often meant aiding with the painting of backgrounds and secondary figures (O'Malley, 2013, 48):

A crucial aspect of painting ... was that it could be taught and delegated. While there were some parts of most commissioned works that only the master would paint, assigning the painting of secondary aspects surely freed up a master's time to a certain extent, though overseeing and correcting the work of assistants almost certainly constituted a large proportion of the input a master had in this stage of work. ${ }^{42}$

For example, an altarpiece by Andrea del Verrocchio, commissioned to him by monks of Vallombrosa, representing the Baptism of Christ by Saint John the Baptist includes two minor figures of

\footnotetext{
${ }^{39}$ Wage data for di Bicci's workshop can be found in Diorio (2013, 219-221).

${ }^{40}$ See, for instance, Wackernagle $(1981,327)$, O'Malley $(2005,68)$, and Diorio $(2013,54)$.

${ }^{41}$ For instance Cennini (1933) advised his readers to always buy mercury sulfide "unbroken" because merchants were know to mix it with "red lead or pounded brick."

${ }^{42}$ O'Malley $(2013,158)$.
} 
knelling angels. One of these angels was painted by a young Leonardo da Vinci, who at the time was working in Verrocchio's workshop. According to (Vasari, 1998, 236), whose attribution of the angel to da Vinci is widely accepted by art historians (Dunkerton, 2011), da Vinci's minor figure was so superior in quality to the rest of the painting that it drove Verrocchio into retirement.

The tasks performed inside the workshop by a master's assistants were crucial to the satisfactory execution of the commission. If done poorly, the overall quality of the painting would have been compromised. By entrusting them to his own employees, the master could mitigate this risk though direct monitoring and direction of their performance. For instance, the faulty preparation of either pigments or glue could affect both the look and the structural stability of the work. If badly mixed paint could lead to severe discoloration of a fresco or altarpiece. A section of the painting that was meant to be light and bright may turn dark and opaque in a short time, ruining its overall look. If put together with a weak glue the altarpiece may fall apart and break, causing irrevocable damage to the painting. In either case, the master was liable for these damages and would have been responsible for the repairs (O'Malley, 2005, 80). If these tasks had been performed by an independent contract out of his sight, the master could not have as easily established whether they had been done with the necessary care. Unlike independent contractors, for instance, bottega employees had nothing to gain from using cheaper materials to make paint. Moreover, the master's education provided him with the human capital necessary to evaluate the performance of these same tasks. During their several years of apprenticeship, as aspiring painters, masters would have learned all the techniques, all the jobs and tasks that they were now assigning to their subordinates. Thus, the monitoring costs associated with these tasks would have been lower than those of more specialized ones. The same argument holds for the painting of secondary sections by one's assistants. The ability to direct the execution of this assignment would have been particularly important to preserve the artist's vision for the painting and give it a cohesive look and consistent style.

\subsubsection{Tasks performed by independent contractors}

Our model predicts that an artist-owner will rely on independent contractors when a task shows high benefits from specialization, does not require the master's direct supervision, and its performance can be inferred easily from its outcome. Historically, Renaissance painters entrusted specialists from outside the bottega for such highly specialized tasks as woodworking and gilding.

Of all individuals who contributed to a painting and were not in the employment of the artist, the carpenter was possibly the most important (Thomas, 1995, 154). His contribution to the final painting was significant. There could be no altarpiece without the wood panel (or panels) that served as the foundation to the layers of gesso which hosted the painting. Moreover 
no altarpiece was complete without a frame. Indeed "the frame was often the most expensive part of a pictorial commission" (Welch, 2000, 108). O'Malley (2013) estimates that, on average, the frame accounted for eighteen percent of the total price of an altarpiece and, occasionally, half of the commission money may be spent on the frame alone. Carpenters had a considerable comparative advantage over the painter. Unlike that of pigments, the production of woodwork had sources of demand other than painters. Carpenters served the needs of all sorts of businesses as well as those of private households. This provided them with an incentive to make large investments in the skills and tools of this craft, beyond what an artist could reasonably afford or wish to acquire.

We can gather information on the relationship between painters and carpenters from di Bicci's Ricordanze (Di Bicci, 1976). Here, di Bicci kept detailed notes on the expenses his workshop incurred in the production of over two-hundred art works. His notes show that he required the services of carpenters in at least twenty-six separate occasions. In half of these, the carpenter of choice was a Giuliano da Maiano. In seven more, Neri hired a carpenter named Domenicho and/or his son Zanobi and he hired a Luca Manucci for other five jobs. ${ }^{43}$ This suggests that painters and carpenters expected to collaborate on multiple projects over the decades. It also shows that master painters relied on specialized workers when it came to the carpentry necessary to complete an altarpiece. The Ricordanze provide some further information about this business relationship. For example, one entry contains the specifications he had given carpenter Maiano for the production of a panel for a commissioned altarpiece. ${ }^{44}$ These included the size, style, and structure of the panel Maiano was to produce. Given the objective nature of these characteristics, Neri could easily check that Maiano had followed his direction upon delivery. In fact, the actual panel, which can still be seen today in the Church for which it was commissioned, "clearly matches the description made by Neri" (Diorio, 2013, 45).

Gilding was another task that required the contribution of a specialist. The practice of using gold leaf on altarpieces and even frescoes was highly popular during the Renaissance. Fifty of the contracts in our data-set mention that the painting had to contain some gold. A commission may also direct the artist on where the gold had to be applied. Thus, a contract from 1521 between Perugino and the Church of Santa Maria Maggiore in Spello read that "the frames [were to be covered] with gold, and the planets [which were to appear in the background] all done in fine gold." 45 Another commission, between Battista di Niccoló and the City of Siena, specified that the background of the painting had to be covered in gold, and that the name of Jesus was also to appear on the panel and made of gold. In most cases however, the text of the contract left a master the choice of how to employ the gold leaf as he found more appropriate.

\footnotetext{
${ }^{43}$ Of the two remining entries, one mentions the carpenter Lucha di Beninchasa and one does not identify the woodworker by name.

${ }^{44}$ The text of this entry is quoted in Diorio $(2013,45)$.

${ }^{45}$ Chambers' translation (Chambers, 1970).
} 
Unsurprisingly, Vasari $(1998,224)$ reports that there existed "very close relations and almost a constant intercourse ... between goldsmiths and painters." During the Renaissance, gilding paintings was so popular that it came to be seen as "a specialization within the art of painting." The application of gold on the surface of the painting was a process that required highly specialized knowledge and tools (O'Malley, 2005, 57). All gilding was done before any painting took place. The gilder would "beat" the gold leaf onto large sections of the surface, which would then be painted over by the master and his assistants, leaving the gilded surfaces exposed only where required. This meant that some of the gold was completely covered by paint and thus not visible. However, having the gilding performed first ensured that the gilder could do no damage to the rest of the painting (O'Malley, 2005, 57).

Commission contracts do not shed much light on the specifics of the "constant intercourse" between painters and goldsmiths. However, "[i]t was common for a specialized gilder, known as mettitoro d'oro, to apply the metal leaf to the [surface of the painting]" (Diorio, 2013, 49). Indeed, even though the gilding of paintings was extremely popular, workshops did not retain the services of a goldsmith. ${ }^{46}$

\section{Conclusion}

This paper develops a theory of the organization of production of paintings in Renaissance Italy. We introduce a simple model to account for key features of the economic life of master painters during this period. First, we show that allocating residual claimancy to the artist, as opposed to any other specialized artisans involved in the fulfilment of commissions, economizes on the costs of ensuring the performance of those tasks that have the greatest effect on the ultimate value of a painting. Second, we show that even a talented artist would have performed tasks over which he had no comparative advantage. Finally, it provides a rationale for the masters' allocation of the remaining tasks between employees of the bottega and independent contractors. In making this choice, a painter must weight the relative costs of delegating a task to a subordinate - which enables him to direct and supervise its performance - and those of delegating the same task to an independent contractor.

While we are prevented from direct quantitative tests of our theory due to data limitations on the inner workings of Renaissance workshops, the historical record is consistent with the implications of our model. Master painters did assume residual claimancy over the execution of commissions. They did head their own firms, hiring employees and independent contractors to aid them in the process, but maintaining ultimate liability over the final product. These painters

\footnotetext{
${ }^{46}$ Neri di Bicci seems to have been one exception (Diorio, 2013, 49). However, Diorio also notes that Bicci relied on gilding for his paintings to an "unusual" degree compared to his peer.
} 
performed all of the key artistic tasks that were necessary for the satisfactory fulfillment of the commission, but also tasks that may have been entrusted to others if it weren't for informational asymmetries. Those tasks that were kept within a painter's workshop were ones that required the master's direct supervision in order to ensure consistency with his vision. These were also tasks that, if left to independent contractors, introduced room for opportunism - for instance, by mixing cheaper materials in the paint. Finally, masters relied on independent contractors, who operated their separate workshops, for such highly specialized tasks as gilding and woodworking since masters could infer performance by observing their outcome upon purchase.

While we develop our model specifically to address the problem of the organization of the production of Renaissance paintings, its logic is potentially of broader applicability to aspects of other industries in the art world. As long as the production of a work of art requires the performance of several tasks, each contributing to its ultimate value to a varying degree, then our argument should shed light on the allocation of ownership and tasks in the relevant industry.

Consider for instance the case of the motion picture industry. Movies are complex art products and making them requires the performance of many diverse tasks, some (such as the writing of the screenplay and the direction) more "artistic" than others (such as make-up and costume design). Even so, the movies themselves vary drastically in their artistic content. ${ }^{47}$ From the logic of our argument, we expect that directors will have greater control over the film-making process when making movies of higher artistic content.

Or consider a comparison between movies and tv-shows. Keeping artistic content constant, the two formats vary in the relative import to the final product of plot, script, and directorial choices, with the former playing a more substantial role in tv-shows and the latter two in movies. ${ }^{48}$ Predictably, directors are much less likely to be the ones with the creative control over the production of tv-shows. Instead, the show-runner, who is usually the writer responsible for planning the plot for the whole series, is the person in charge. Both directors and writers tasked with the dialogue for individual episodes have much less creative power and their decisions are supervised by the show-runner. Movie franchises, which have become increasingly popular over the past two decades, share with tv-shows a greater emphasis on plot across entries (each entry having to set up the next). Notoriously, the directors of franchise movies have reduced creative control over the final product, which is instead exercised by franchise producers, figures more akin to tv-show-runners and executive producers.

The model may also be employed to explains why directors, especially those making films

\footnotetext{
${ }^{47}$ We do not take a position here on the question of what makes something "art." We merely take as given that artists, critics, and the public perceive some products as more artistic than others.

${ }^{48}$ This is not to say that script and directorial choices do not matter in tv-shows, especially ones of high artistic value. Our argument merely relates to their relative importance to the final product between the two media.
} 
d'auteur, are more likely to both write and direct their movies. For example, critically acclaimed directors like Quentin Tarantino, Joel and Ethan Coen, Martin Scorsese, and Francis Ford Coppola are also often credited with writing the script for their movies. Our argument predicts that such a dual role will be less common in movies of lower artistic content.

Another potential application comes from the publishing industry. Poetry and fiction both require some artistic talent. They also require the performance of more mundane tasks, like line editing. Our model suggests that, since the crafting of each individual sentence and specific wordchoice are more central to poetry than to fiction, poets will be less likely to entrust line editing to someone else. Hence, historically poets have enjoyed a licence poétique, the licence to violate standard rules of grammar in their writing. Similarly, the model sheds light on the variation in the prevalence of co-authorship across writing genres. Very little poetry is ever co-authored, and novels are also generally single-authored, while the practice is more common in the world of non-fiction, where the artistic content of a book is generally rather low. 
Appendix: List of Commission Contracts 


\begin{tabular}{|c|c|c|c|}
\hline & Year of commission & Painters awarded the commission & Source of the contract \\
\hline 1 & 1460 & Alesso Baldovinetti & Chambers (1970) \\
\hline 2 & 1490 & Domenico Ghirlandaio \& Davide Ghirlandaio & Chambers (1970) \\
\hline 3 & 1521 & Pietro Perugino & Chambers (1970) \\
\hline 4 & 1481 & Cosimo Rosselli, Pietro Perugino, Domenico Ghirlandaio, \& Alessandro Botticelli & Chambers (1970) \\
\hline 5 & 1502 & Pinturicchio & Chambers (1970) \\
\hline 6 & 1445 & Piero della Francesca & Chambers (1970), Meiss (1941) \\
\hline 7 & 1461 & Benozzo Gozzoli & Chambers (1970) \\
\hline 8 & 1492 & Giovanni Bellini \& Gentile Bellini & Chambers (1970) \\
\hline 9 & 1515 & Giovanni Bellini & Chambers (1970) \\
\hline 10 & 1503 & Pietro Perugino & Chambers (1970) \\
\hline 11 & 1472 & Baldassare Estense & Chambers (1970) \\
\hline 12 & 1430 & Antonio Di Giovanni d'Anghiari & Banker (1991) \\
\hline 13 & 1437 & Sassetta & Banker (1991) \\
\hline 14 & 1439 & Sassetta & Banker (1991) \\
\hline 15 & 1447 & Fra Angelico & Douglas (1902) \\
\hline 16 & 1518 & Ridolfo Ghirlandaio & Brown (1988) \\
\hline 17 & 1508 & Luca Signorelli & Matthew (1988) \\
\hline 18 & 1511 & Lorenzo Lotto & Matthew (1988) \\
\hline 19 & 1518 & Rosso Fiorentino & Franklin (1987) \\
\hline 20 & 1505 & Raphael & Franklin (1987) \\
\hline 21 & 1460 & Filippo Lippi & Mendelsohn (1909) \\
\hline 22 & 1285 & Duccio & Milanesi (1856) \\
\hline 23 & 1308 & Duccio & Milanesi (1856) \\
\hline 24 & 1382 & Bartolo di Fredi & Milanesi (1856) \\
\hline 25 & 1402 & Giovanni di Pietro da Napoli \& Martino di Bartolomeo & Milanesi (1856) \\
\hline 26 & 1454 & Benedetto Bonfigli & Mancini (1992) \\
\hline 27 & 1469 & Benedetto Bonfigli & Bombe (2018) \\
\hline 28 & 1445 & Piero della Francesca & Milanesi (1901) \\
\hline 29 & 1454 & Piero della Francesca & Milanesi (1901) \\
\hline 30 & 1466 & Piero della Francesca & Milanesi (1901) \\
\hline 31 & 1474 & Bartolomeo della Gatta & Pieri (1989) \\
\hline 32 & 1486 & Bartolomeo della Gatta & Ghizzi (1885) \\
\hline 33 & 1501 & Bartolomeo della Gatta & Droandi (2002) \\
\hline 34 & 1447 & Benozzo Gozzoli & Ahl (1996) \\
\hline 35 & 1466 & Benozzo Gozzoli & Pecori (1853) \\
\hline 36 & 1484 & Neroccio de' Landi & Milanesi (1856) \\
\hline 37 & 1500 & Raphael & Graziani (1908) \\
\hline 38 & 1407 & Spinello Aretino \& Martino di Bartolomeo & Milanesi (1856) \\
\hline 39 & 1425 & Battista di Niccoló & Milanesi (1856) \\
\hline 40 & 1442 & Priamo della Quercia & Milanesi (1856) \\
\hline 41 & 1447 & Sassetta & Milanesi (1856) \\
\hline 42 & 1447 & Giovanni di Paolo & Milanesi (1856) \\
\hline 43 & 1448 & Sano di Pietro & Milanesi (1856) \\
\hline 44 & 1458 & Nastagio di Gasparre & Milanesi (1856) \\
\hline 45 & 1471 & Matteo di Giovanni & Milanesi (1856) \\
\hline 46 & 1482 & Luca Signorelli & Mancini (1904) \\
\hline 47 & 1483 & Pietro Perugino & Canuti (1931) \\
\hline 48 & 1488 & Pietro Perugino & Battistelli (1974) \\
\hline 49 & 1498 & Pietro Perugino & McLellan (1992) \\
\hline 50 & 1495 & Pietro Perugino & Canuti (1931) \\
\hline 51 & 1496 & Pietro Perugino & Canuti (1931) \\
\hline 52 & 1497 & Pietro Perugino & von Teuffel (1995) \\
\hline 53 & 1497 & Pietro Perugino & von Teuffel (1995) \\
\hline 54 & 1499 & Pietro Perugino & von Teuffel (1995) \\
\hline 55 & 1507 & Pietro Perugino & Canuti (1931) \\
\hline 56 & 1507 & Pietro Perugino & Canuti (1931) \\
\hline 57 & 1512 & Pietro Perugino & Canuti (1931) \\
\hline 58 & 1512 & Pietro Perugino & Sartore (2015) \\
\hline 59 & 1493 & Luca Signorelli & Martini (2009) \\
\hline 60 & 1494 & Luca Signorelli & Pungileoni (1822) \\
\hline 61 & 1499 & Luca Signorelli & Pungileoni (1822) \\
\hline 62 & 1507 & Giovanni di Pietro detto lo Spagna & Sabatini (1984) \\
\hline 63 & 1516 & Giovanni di Pietro detto lo Spagna & Sabatini (1984) \\
\hline 64 & 1500 & Luca Signorelli & McLellan (1992) \\
\hline 65 & 1508 & Luca Signorelli & Anselmi (1892) \\
\hline 66 & 1509 & Luca Signorelli & Italain Renaissance Document Site: http://irds-project.org/doc/601/ \\
\hline 67 & 1515 & Luca Signorelli & Mancini (1867) \\
\hline 68 & 1519 & Luca Signorelli & Italain Renaissance Document Site: http://irds-project.org/doc/584/558/ \\
\hline 69 & 1519 & Luca Signorelli & Henry (1998) \\
\hline 70 & 1521 & Luca Signorelli & Manni (1756) \\
\hline 71 & 1524 & Tommaso Barnabei & Italain Renaissance Document Site: http://irds-project.org/doc/765/ \\
\hline 72 & 1523 & Lorenzo Lotto & Annibaldi (1980) \\
\hline 73 & 1305 & Vanni & Tanfani-Centofani (1897) \\
\hline 74 & 1418 & Battista di Gerio & Tanfani-Centofani (1897) \\
\hline 75 & 1494 & Jacopo da Montagnana & Sartori (1976) \\
\hline 76 & 1472 & Angelo Zotto & Sartori (1976) \\
\hline
\end{tabular}




\section{References}

Ahl, D. C. (1996). Benozzo Gozzoli: Tradition and Innovation in Renaissance Painting. Yale University Press.

Allen, D. and Lueck, D. (1992). Contract choice in modern agriculture: cash rent versus cropshare. The Journal of Law and Economics, 35(2):397-426.

Allen, D. W. and Lueck, D. (1998). The nature of the farm. The Journal of Law and Economics, 41(2):343-386.

Annibaldi, G. (1980). Documenti d'archivio sull'allogazione a Lorenzo Lotto della pala d'altare della Santa Lucia di Jesi. Notizie da Palazzo Albani, 1-2:143-148.

Anselmi, A. (1892). Instrumenti di allogazione e di quietanza della tavola di Luca Signorelli figurante il Battesimo. Archivio Storico dell'Arte, 5(1):196-197.

Banker, J. R. (1991). The program for the Sassetta altarpiece in the Church of S. Francesco in Borgo S. Sepolcro. I Tatti Studies in the Italian Renaissance, 4:11-58.

Barzel, Y. (1987). The entrepreneur's reward for self-policing. Economic Inquiry, 25(1):103-116.

Battistelli, F. (1974). Notizie e documenti sull'attività di Perugino a Fano. Antichita Viva, 12:65569.

Baxandall, M. et al. (1988). Painting and Experience in Fifteenth Century Italy: A Primer in the Social History of Pictorial Style. Oxford University Press.

Becker, G. S. and Murphy, K. M. (1992). The division of labor, coordination costs, and knowledge. The Quarterly Journal of Economics, 107(4):1137-1160.

Berenson, B. (1980). The Italian Painters of the Renaissance. Phaidon.

Bombe, W. (2018). Die Tafelbilder, Gonfaloni und Fresken des Benedetto Bonfigli. De Gruyter.

Bondanella, J. C. and Bondanella, P. (1998). Introduction. Lives of the Artists: A New Translation by Julia C. Bondanella and Peter Bondanella, pages vi-xv.

Borowiecki, K. J. (2013). Geographic clustering and productivity: An instrumental variable approach for classical composers. Journal of Urban Economics, 73(1):94-110.

Brown, A. (1988). A contract for Ridolfo Ghirlandaio's' Pietà in S. Agostino, Colle Val d'Elsa. Burlington Magazine, 130(1026):692-693. 
Canuti, F. (1931). Il Perugino. La Diana.

Caves, R. E. (2000). Creative Industries: Contracts Between Art and Commerce. Harvard University Press.

Caves, R. E. (2006). Organization of arts and entertainment industries. Handbook of the Economics of Art and Culture, 1:533-566.

Cennini, C. (1933). The Craftsman's Handbook. Dover Publications.

Chambers, D. S. (1970). Patrons and Artists in the Italian Renaissance. Palgrave.

Cheung, S. N. (1983). The contractual nature of the firm. The Journal of Law and Economics, 26(1):1-21.

Chisholm, D. C. (1993). Asset specificity and long-term contracts: The case of the motion-pictures industry. Eastern Economic Journal, 19(2):143-155.

Chisholm, D. C. (1997). Profit-sharing versus fixed-payment contracts: Evidence from the motion pictures industry. The Journal of Law, Economics, and Organization, 13(1):169-201.

Comanducci, R. M. (2000). Fattori e garzoni al lavoro nelle botteghe d'arte. Arti Fiorentine, $3: 41-55$.

Constable, W. G. (1948). The painter's workshop. Bulletin of the American Academy of Arts and Sciences, 1(5):2-5.

Constable, W. G. (1954). The Painter's Craft: Practices, Techniques and Materials. Dover Publications.

De Marchi, N. and Van Miegroet, H. J. (2006). The history of art markets. In Ginsburgh, V. A. and Throsby, D., editors, Handbook of the Economics of Art and Culture, pages 69-122. Elsevier.

Di Bicci, N. (1976). Ricordanze. Brill.

Diorio, J. A. (2013). The Production Methods of Neri di Bicci and the Prevalence of Cartoon Usage in Fifteenth-Century Florence. PhD Dissertation, Queen's University.

Douglas, R. L. (1902). Fra Angelico. G. Bell and Sons.

Droandi, I. (2002). Le Insegne della Fraternità dei Laici nel XVI secolo: Da Bartolomeo della Gatta a Giorgio Vasari. All'Insegna del Giglio. 
Dunkerton, J. (2011). Leonardo in Verrocchio's Workshop: Re-examining the technical evidence. National Gallery Technical Bulletin, 32:4-31.

Etro, F. (2018). The economics of Renaissance art. The Journal of Economic History, 78(2):500538.

Etro, F., Marchesi, S., and Pagani, L. (2015). The labor market in the art sector of Baroque Rome. Economic Inquiry, 53(1):365-387.

Etro, F. and Pagani, L. (2012). The market for paintings in Italy during the seventeenth century. The Journal of Economic History, 72(2):423-447.

Etro, F. and Pagani, L. (2013). The market for paintings in the Venetian Republic from Renaissance to Rococò. Journal of Cultural Economics, 37(4):391-415.

Fama, E. F. and Jensen, M. C. (1983). Agency problems and residual claims. The Journal of Law and Economics, 26(2):327-349.

Franklin, D. (1987). Rosso, Leonardo Buonafe and the Francesca de Ripoi Altarpiece. The Burlington Magazine, 129(1015):652-662.

Galenson, D. W. (2009). Conceptual Revolutions in Twentieth-Century Art. Cambridge University Press.

Galenson, D. W. (2011). Old Masters and Young Geniuses. Princeton University Press.

Galenson, D. W. and Weinberg, B. A. (2000). Age and the quality of work: The case of modern American painters. Journal of Political Economy, 108(4):761-777.

Ghizzi, G. (1885). Storia della Terra di Castiglione Fiorentino. Bellotti.

Goldthwaite, R. A. (1993). Wealth and the Demand for Art in Italy, 1300-1600. Johns Hopkins University Press.

Goldthwaite, R. A. (2009). The Economy of Renaissance Florence. Johns Hopkins University Press.

Graziani, G. M. (1908). Documenti Inediti Relativi al "San Nicola da Tolentino" e allo "Sposalizio" di Raffaello. Unione Tipografica Cooperativa.

Greenwald, D. S. (2019). Modernization and rural imagery at the Paris Salon: an interdisciplinary approach to the economic history of art. The Economic History Review, 72(2):531-567. 
Greenwald, D. S. (2021). Painting by Numbers. Princeton University Press.

Hellmanzik, C. (2010). Location matters: Estimating cluster premiums for prominent modern artists. European Economic Review, 54(2):199-218.

Henry, T. (1998). Signorelli in British Collections. National Gallery Publications.

Hölmstrom, B. (1979). Moral hazard and observability. The Bell Journal of Economics, 10(1):7491.

Hunt, E. S., Murray, J. M., Murray, J., et al. (1999). A history of business in medieval Europe, 1200-1550. Cambridge University Press.

Kelly, E. and O'Hagan, J. (2007). Geographic clustering of economic activity: The case of prominent western visual artists. Journal of Cultural Economics, pages 109-128.

Mancini, F. F. (1992). Benedetto Bonfigli. Galleria Nazionale dell'Umbria.

Mancini, G. (1867). Notizie sulla Chiesa del Calcinaio e sui Diritti che vi ha il Comune di Cortona. Tipografia Bimbi.

Mancini, G. (1904). Allogazione al Signorelli d'alcuni dipinti in Lucignano. Rivista d'Arte, 2(8):187.

Manni, D. M. (1756). Vita di Luca Signorelli, Pittore Cortonese. Carnesecchi.

Martini, L. (2009). Tesori d'Arte dal Trecento all'Ottocento: Restauri a Montepulciano. Museo Civico di Montepulciano.

Matthew, L. C. (1988). New evidence for Lotto's career in Jesi. The Burlington Magazine, 130(1026):693-697.

McLellan, D. E. (1992). Luca Signorelli's Last Judgement Fresco Cycle at Orvieto: An Interpretation of the Fears and Hopes of the Comune and People of Orvieto at a Time of Reckoning. $\mathrm{PhD}$ thesis.

Meiss, M. (1941). A documented altarpiece by Piero della Francesca. The Art Bulletin, 23(1):5368.

Mendelsohn, H. (1909). Fra Filippo Lippi. J. Bard.

Milanesi, G. (1856). Documenti per la Storia dell'Arte Senese. Onorato Porri.

Milanesi, G. (1901). Documenti Inediti dell'Arte Toscana dal XII al XVI Secolo. Libreria Antiquaria Dotti. 
Montias, J. M. (1987). Cost and value in seventeenth-century dutch art. Art History, 10(4):455466.

Montias, J. M. (1990). Socio-economic aspects of netherlandish art from the fifteenth to the seventeenth century: a survey. The Art Bulletin, 72(3):358-373.

Nees, L. (2002). Early Medieval Art. Oxford University Press.

Nethersole, S. (2019). Art of Renaissance Florence: A City and Its Legacy. Laurence King Publishing.

O'Malley, M. (2005). The Business of Art: Contracts and the Commissioning Process in Renaissance Italy. Yale University Press.

O’Malley, M. (2013). Painting Under Pressure: Fame, Reputation and Demand in Renaissance Florence. Yale University Press.

Owen, V. L. (1977). The Florentine and Sienese renaissance: A monopsonistic explanation. Journal of Cultural Economics, 1(1):33-55.

Pecori, L. (1853). Storia della Terra di San Gimignano Scritta dal Canonico Luigi Pecori. Tipografia Galileiana.

Pieri, S. (1989). Documentazione Minore per la Storia Aretina. Brigata Aretina.

Pungileoni, L. (1822). Elogio Storico di Giovanni Santi Pittore e Poeta, Padre del Gran Raffaello di Urbino. V. Guerrini.

Sabatini, F. G. (1984). Giovanni di Pietro detto lo Spagna. Accademia Spoletina.

Sartore, A. M. (2015). Una Tavola "Con Ricco Ornamento Intorno". Le Decorazioni della "Capsa" del Polittico di Sant'Agostino in Perugia. Nuovi Documenti., pages 164-166. Musée JacquemartAndré.

Sartori, A. (1976). Documenti per la Storia dell'Arte a Padova. N. Pozza.

Sekules, V. (2001). Medieval Art. Oxford University Press.

Shearman, J. (1983). The organization of raphael's workshop. Art Institute of Chicago Museum Studies, 10(1):41-57.

Stigler, G. J. (1951). The division of labor is limited by the extent of the market. Journal of Political Economy, 59(3):185-193. 
Tanfani-Centofani, L. (1897). Notizie di Artisti Tratte dai Documenti Pisani. Enrico Spoerri Editore.

Thomas, A. (1995). The Painter's Practice in Renaissance Tuscany. Cambridge University Press.

Tietze, H. (1939). Master and workshop in the Venetian Renaissance. Parnassus, 11(8):34-45.

Vasari, G. (1998). The Lives of the Artists: A New Translation by Julia C. Bondanella and Peter Bondanella. Oxford University Press.

von Teuffel, C. G. (1995). The contract for Perugino's Assumption of the Virgin at Vallombrosa. Burlington Magazine, 137(1106):307-312.

Wackernagel, M. (1981). The World of the Florentine Renaissance Artist: Projects and Patrons, Workshop and Art Market. Princeton University Press.

Welch, E. S. (2000). Art in Renaissance Italy, 1350-1500. Oxford University Press. 